INTERNATIONAL MONETARY FUND

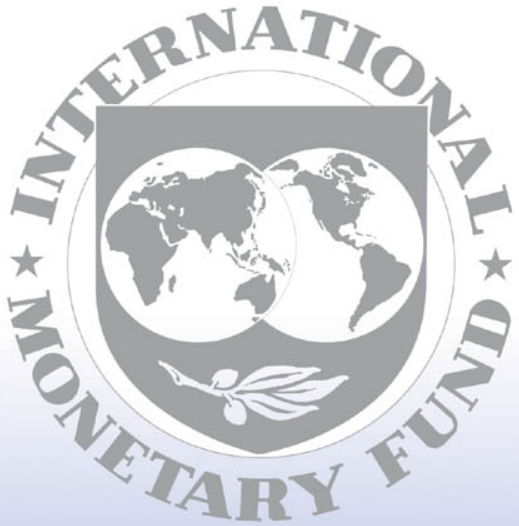

Staff

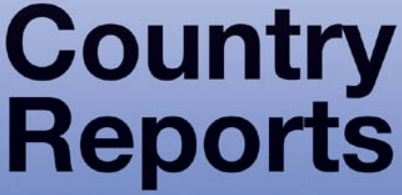




\section{Japan: Selected Issues}

This Selected Issues paper for Japan was prepared by a staff team of the International Monetary Fund as background documentation for the periodic consultation with the member country. It is based on the information available at the time it was completed on June 16, 2009. The views expressed in this document are those of the staff team and do not necessarily reflect the views of the government of Japan or the Executive Board of the IMF.

The policy of publication of staff reports and other documents by the IMF allows for the deletion of market-sensitive information.

Copies of this report are available to the public from

International Monetary Fund $\bullet$ Publication Services

700 19th Street, N.W. • Washington, D.C. 20431

Telephone: (202) 623-7430 • Telefax: (202) 623-7201

E-mail: publications@imf.org • Internet: http://www.imf.org

\section{International Monetary Fund Washington, D.C.}


This page intentionally left blank

CInternational Monetary Fund. Not for Redistribution 


\section{INTERNATIONAL MONETARY FUND}

\section{JAPAN}

\section{Selected Issues}

Prepared by Marco Espinosa-Vega (MCM), Sumiko Ogawa (OAP), Juan Solé (MCM), Chad Steinberg (OAP), Murtaza Syed (APD), and Kiichi Tokuoka (APD)

Approved by the Asia and Pacific Department

June 16, 2009

Contents

I. The Outlook for Financing Japan's Public Debt

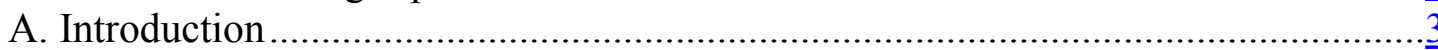

B. Outlook for Absorption Capacity of the JGB Market ..............................................

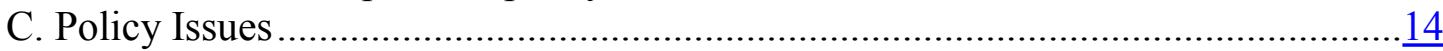

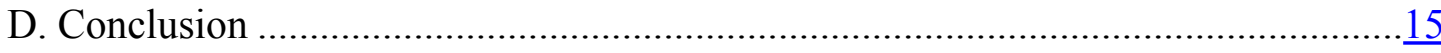

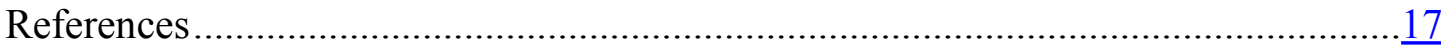

II. Japan and the Global Financial System: Spillovers and Systemic Linkages ......................18

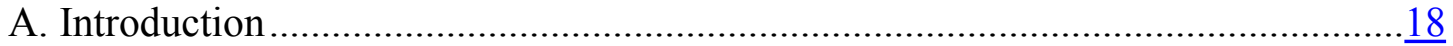

B. Cross-Border Financial Linkages in Japan: Recent Developments ………............18

C. Network Analysis: Assessing Systemic Linkages using Banking Exposures ……..20

D. The Co-Risk Model: Market Perceptions of Spillovers.........................................25

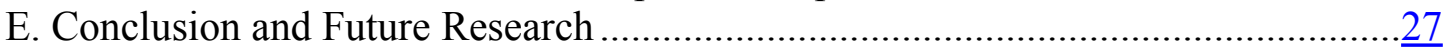

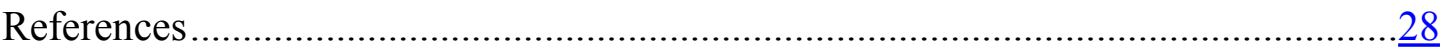

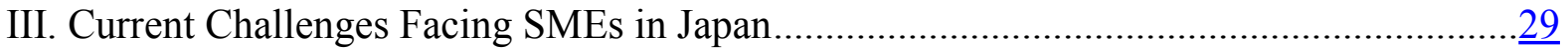

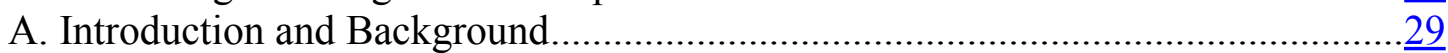

B. Financial Position of the Corporate Sector .........................................................

C. Promoting Restructuring of the Corporate Sector..................................................

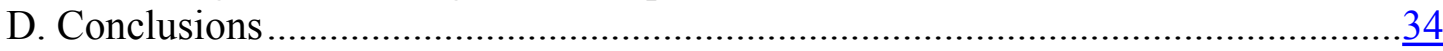

Boxes

III.1. Court-Led Options for Financially Distressed Firms...................................................

Tables

I.1. Medium-term Assumptions on Interest Rate and Growth .........................................

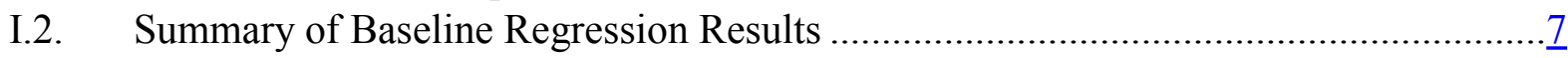

I.3. Baseline Regression Results ..........................................................................

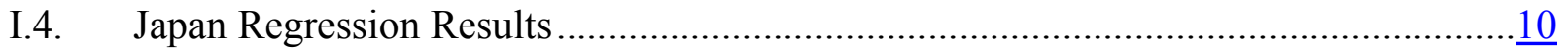




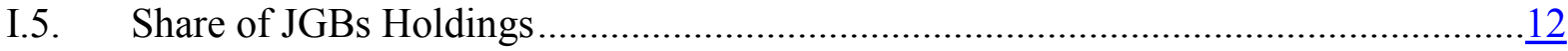

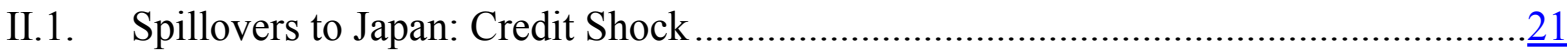

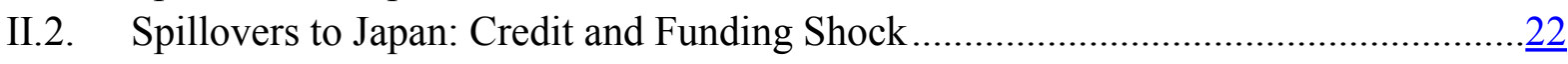

II.3. Full Sample: Impacts of Credit and Funding Shock …………................................23

II.4. Spillovers to Japan: Contagion Paths from Credit and Funding Shock ........................24

II.5. Spillovers from Japan: Credit and Funding Shock ..................................................

Figures

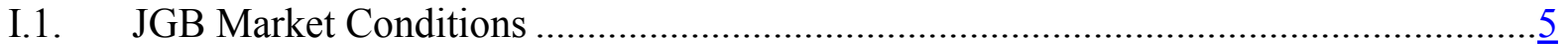

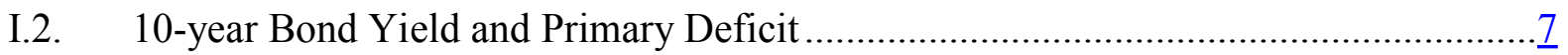

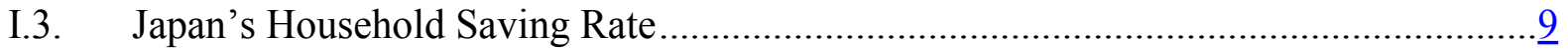

I.4. Flow of Funds of the Household Sector ………...................................................

II.1. Japan: A Diagrammatic Depiction of Co-Risk Feedbacks between U.S., European,

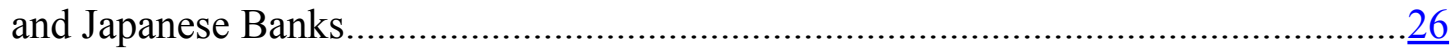

Appendices

I.1. Appendix 


\section{The Outlook for Financing JaPan's Public DebT ${ }^{1}$}

\section{Summary}

In Japan, government bond yields have shown little sensitivity to changes in the debt stock or fiscal deficits over the past ten years. Despite net public debt increasing by 40 percent of GDP, 10-year JGB yields have remained below 2.0 percent. Possible factors include: Japan's large and growing pool of household savings, stable institutional investors, and a strong home bias. The large financial surpluses of the corporate sector in recent years may also have played a supporting role in providing funds through the banking system.

However, going forward, the market's capacity to absorb debt is likely to diminish as population aging reduces savings inflows and reforms improve financial intermediation (e.g., Japan Post Bank). This could in turn strengthen the link between JGB yields and the stock of public debt. In the near term, sound public debt management can help preserve market stability, but over a longer-horizon, fiscal consolidation will become critical for the smooth financing of government operations.

\section{A. Introduction}

1. Japan faces a very difficult fiscal situation. After several years of improvement, fiscal deficits have widened sharply, reflecting both discretionary measures and automatic stabilizers in the slowdown. To finance the higher deficit, the government is expected to increase significantly JGB issuances in the coming year. With the general government deficit projected to reach 10 percent of GDP in 2009, public debt will exceed 100 percent of GDP in net terms (215 percent of GDP in gross terms) — one of the highest among advanced economies.

\section{Despite the rapid increase in the supply of JGBs, the market so far has had little} difficulty in absorbing the new debt. Net public debt has increased by about 40 percent of GDP ( 75 percent in gross terms) over the past ten years, while rollover of JGBs and financing bills amount to 40 percent of GDP annually. ${ }^{2}$ Despite this, government bond yields have been remained below 2 percent. Can these benign conditions be expected to continue in the face of even-larger increases in public debt? In this context, this chapter examines the challenges ahead facing Japan's public debt finances, focusing on JGBs, which make up most of public debt, and discusses possible ways of maintaining market stability.

\footnotetext{
${ }^{1}$ Prepared by Kiichi Tokuoka.

${ }^{2}$ The amount of financing bill outstanding was $¥ 109$ trillion (20 percent of GDP) as of end-2008.
} 


\section{B. Outlook for Absorption Capacity of the JGB Market}

3. Japan's medium-term fiscal position is precarious. Under the authorities' current policies (no consumption tax increase is assumed), net public debt is projected to continue rising, exceeding 160 percent of GDP by 2020 (baseline scenario). Under an alternative scenario when nominal interest rate is higher than in the baseline, net public debt would be even higher. ${ }^{3}$

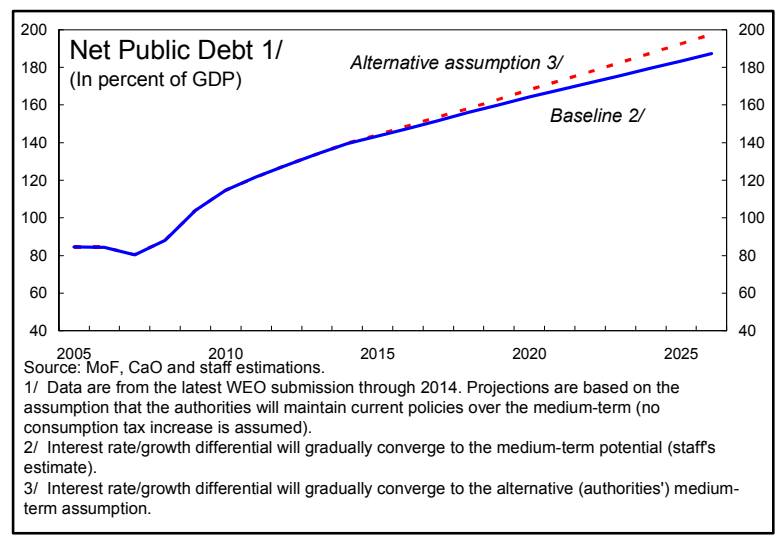

\begin{tabular}{|lcc|}
\hline \multicolumn{3}{|c|}{ Table I.1. Medium-term Assumptions on Interest Rate and Growth } \\
\hline & Baseline & Alternative 1/ \\
\hline Nominal interest rate on public debt & 2.9 & 4.1 \\
Real GDP growth & 1.2 & 1.1 \\
Inflation rate & 1.0 & 1.7 \\
\hline 1/ Authorities' baseline assumptions for FY2018 as of January 2009. Nominal interest rate of 4.1 percent on public \\
debt is the assumption for nominal long-term interest rate.
\end{tabular}

4. Standard theory suggests that either the fiscal deficit or the stock of debt should have a positive relation with the government bond yields. A textbook IS-LM framework predicts that deficits which finance expansionary fiscal policy raise interest rates. On the other hand, standard neoclassical growth theory argues that ultimately the stock of debt matters - in equilibrium, the real interest rate should equal the marginal productivity of capital, and thus what matters is the size of crowding-out of private capital by public debt.

\section{In recent years, JGB yields have not} been sensitive to changes in the debt stock or fiscal deficits. Prior to 2000 , the 10 -year JGB yields had declined steadily to 2 percent. Since 2000, 10-year JGB yields have remained fairly stable, despite the accumulation of debt and large fiscal deficits. More recently, the yields have picked up slightly since the beginning of this year (Figure I.1), but still remain low by historical standard.

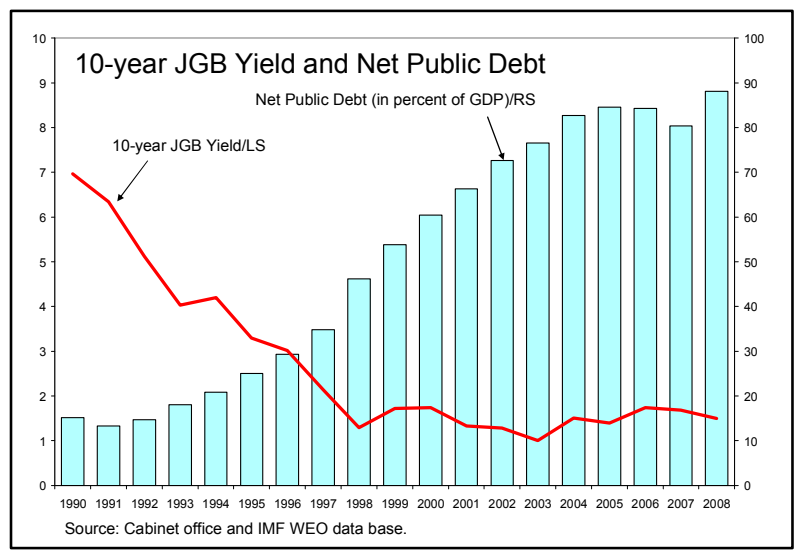

\footnotetext{
${ }^{3}$ For further details, see Appendix II in Japan: 2009 Article IV Consultation—Staff Report.
} 
Figure I.1. JGB Market Conditions
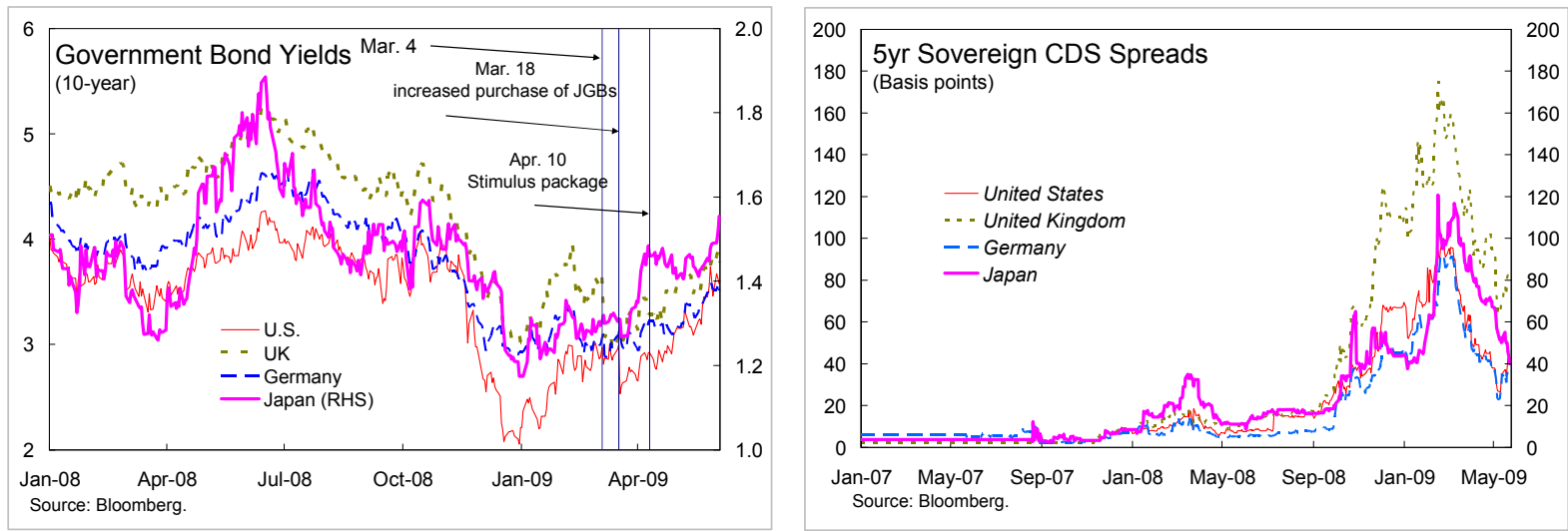

6. This chapter contains an empirical attempt to determine whether JGBs are historically less sensitive to fiscal variables than other sovereign bonds (U.S., U.K., France, and Germany). The purpose is not to pin down the impact of the fiscal deficits or the stock of debt on the yields, but rather to obtain some information to help interpret key differences in Japan's bond market compared with others. The outline of the baseline regressions and key findings are as follows: ${ }^{4}$

\section{Outline of the baseline regressions}

- $\quad$ The dependent variable is the 10-year government bond yield (in percent) or its spread with the short-term interest rate (3-month deposit rate). The main explanatory variable is either the general government primary deficit (in percent of GDP) or general government debt (in percent of GDP) at the end of the previous year (the debt is measured both in net and gross terms). The primary deficit is used instead of the overall deficit as an explanatory variable, since the overall deficit includes interest payment, creating an endogeneity problem. The general government primary deficit is instrumented by its own lag to avoid (or at a minimum to reduce) the effects of the current business cycle. ${ }^{5}$ Standard controls (short-term interest rate, inflation, and real GDP growth) are included in the regressions. The sample period is 1971-2008 for Japan and the U.S. and somewhat shorter for other countries due to limited data availability.

\footnotetext{
${ }^{4}$ Stationarity assumptions on time series data are discussed in Appendix I.1.

${ }^{5}$ A lag of at most two years is chosen to maintain the strength of the instrument (the third lag is often a weak instrument).
} 
Estimated Equations: ${ }^{6}$

(i) 10-year bond yield $=\beta_{0}+\beta_{1}$ general government primary deficit + control variables

(ii) spread $\quad=\beta 0+\beta 1$ general government primary deficit + control variables

(iii) 10-year bond yield $=\beta 0+\beta 1$ general government net (or gross) debt + control variables

\section{Summary results}

- Japan. When the fiscal variable (independent variable) is the primary balance, the coefficient is relatively small (at most 0.1 ) and statistically insignificant. When the net or gross debt is included as an explanatory variable, the coefficient turns negative and significant. ${ }^{7}$ The results are generally coherent across alternative specifications. The estimates do not change much, even if the U.S. 10-year bond yield or its spread with the U.S. short-term interest rate - as a proxy for international liquidity conditions - is included as an explanatory variable. ${ }^{8}$ Similarly, excluding government debt held by the central bank from the net or gross debt (dependent variable) does not affect the results. ${ }^{9}$ Finally, restricting the sample to the pre-deflation period (before 1995) gives a relatively large coefficient (0.2) with a high t-statistic (3.4) when the 10-year bond yield is regressed on the primary balance, but in other specifications (with the restricted sample) the results are similar to those earlier.

- $\quad$ Other countries. For other countries, however, positive coefficients on the primary deficit are reported, and for the U.S. and U.K. they are statistically significant in most cases. These statistically significant coefficients lie in the range of $0.20-0.40$, which can be interpreted as stating that an increase in the primary deficit by one percent of

\footnotetext{
${ }^{6}$ The spread is not regressed on debt, since the former is assumed to be stationary while the latter is unlikely to be so (see Appendix I.1).

${ }^{7}$ This chapter is not the first to report a negative coefficient on public debt. Some earlier articles have also reported negative coefficients across countries using panel data (e.g., Faini, 2006; Ardagna, Caselli, and Lane, 2004) and for some countries using country-by-country time series data (e.g., Caporale and Williams, 2002). One possible interpretation of negative signs is that when the level of sovereign debt is low enough and investors believe that the debt is of high quality, they may switch from low quality debt to sovereign as more sovereign debt is issued, reducing the yield (Caporale and Williams, 2002).

${ }^{8}$ When the U.S. 10-year bond yield is an explanatory variable, cointegration with other variables is assumed. On the other hand, the spread is assumed to be stationary and can be instrumented by its own lag, to avoid the endogeneity problem.

${ }^{9}$ Engen and Hubbard (2004) argue that the effects of government debt held such as by the central bank, which does not crowd out domestic private capital, need to be appropriately controlled for.
} 
GDP leads to an increase in the 10 -year government bond yield by $20-40 \mathrm{bps} .{ }^{10} \mathrm{On}$ the other hand, the coefficients on net or gross debt are again negative.

\begin{tabular}{|lll|}
\hline \multicolumn{3}{l}{ Table I.2. Summary of Baseline Regression Results } \\
\hline Japan & Primary Balance & Net/Gross Debt \\
\hline U.S. and U.K. & $\begin{array}{l}\text { The coefficients are at most } 0.10 \\
\text { and statistically insignificant. }\end{array}$ & The coefficients are negative. \\
& $\begin{array}{l}\text { The coefficient are in the range of } \\
0.20-0.40 \text { and statistically significant } \\
\text { at the 1 percent level in most cases. } \\
\text { France and Germany }\end{array}$ & The coefficients are negative. \\
& $\begin{array}{l}\text { The coefficients are positive, but the } \\
\text { results are not as strong as the U.S. } \\
\text { and U.K. }\end{array}$ \\
\hline
\end{tabular}

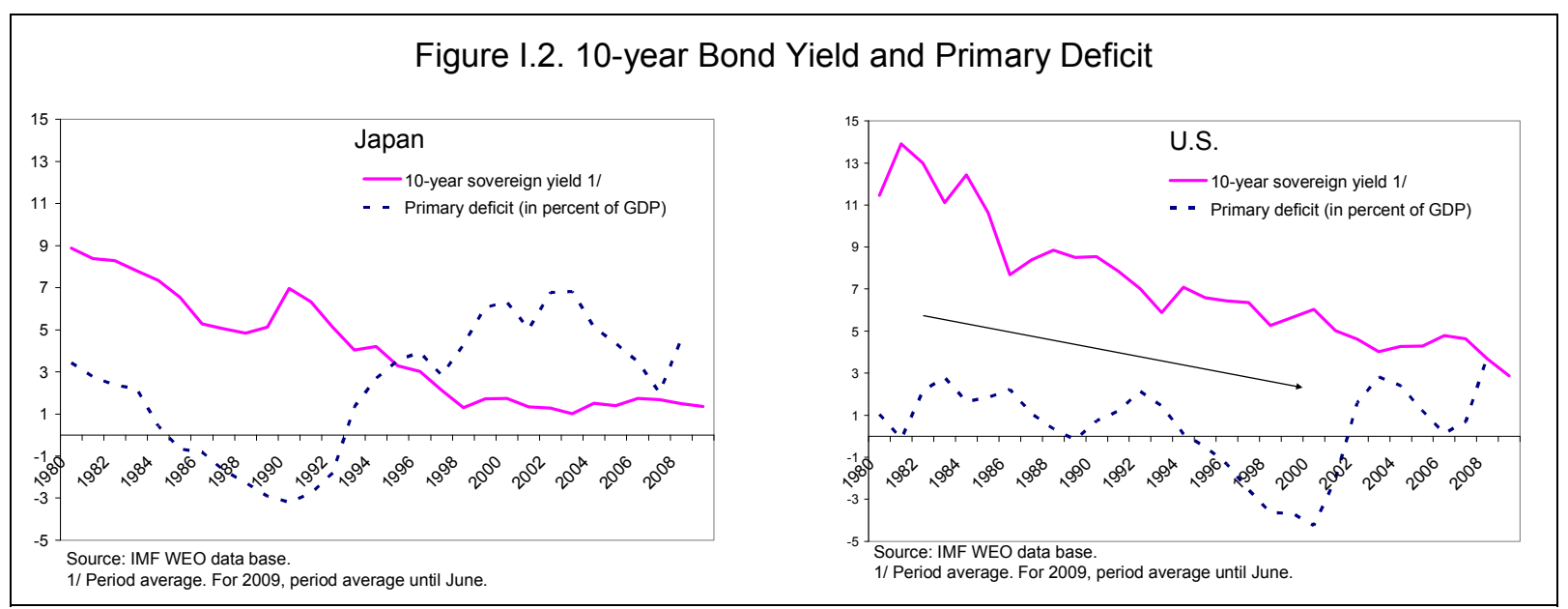

7. While these results appear to suggest that in Japan the government bond yields have been less sensitive to the primary deficit than in other countries, they should be interpreted with caution. In particular, the results may be subject to the omitted variable problem even after using the instrumental variable method. For example, today's yield may be affected by various current business cycle variables, which are not fully accounted for by growth or short-term monetary conditions (which are included in the regressions as controls) but may be correlated with the primary deficit. In principle, it is possible to avoid this problem, for example, by regressing future (expected) yields on deficits forecasted by the national authorities. ${ }^{11}$ However, unfortunately, such an analysis is currently not feasible for Japan, as the Japanese authorities (cabinet office) started to publish its 5-year forecasts for the deficit and the stock of debt only several years ago.

\footnotetext{
${ }^{10}$ These estimates are roughly the same size as those Laubach (2003) obtained, using forecasted fiscal deficits of the U.S.

${ }^{11}$ Laubach (2003) finds empirical evidence that in the U.S. future (expected) yields are responsive to forecasted deficits and debt levels, which are less likely to be affected by the current business cycle.
} 
Table I.3. Baseline Regression Results

\begin{tabular}{|c|c|c|c|c|c|c|c|c|}
\hline & \multirow[t]{2}{*}{ Dependent Variable } & \multirow[t]{2}{*}{ Method } & \multicolumn{3}{|c|}{ Main Independent Variable } & \multirow[t]{2}{*}{ Instrument } & \multirow{2}{*}{$\begin{array}{c}\text { Residual } \\
\text { Unit Root Test } \\
\text { (ADF t stat) }\end{array}$} & \multirow{2}{*}{$\begin{array}{c}\text { Sample } \\
\text { Size }\end{array}$} \\
\hline & & & $\begin{array}{c}\text { Primary } \\
\text { deficit }\end{array}$ & $\begin{array}{l}\text { Net } \\
\text { debt }\end{array}$ & $\begin{array}{c}\text { Gross } \\
\text { debt }\end{array}$ & & & \\
\hline \multicolumn{9}{|c|}{ Japan } \\
\hline (1) & 10-year bonds yield & OLS & $\begin{array}{c}0.09 \\
(1.39)\end{array}$ & - & - & - & -4.16 & 38 \\
\hline$(2)$ & Spread with short-term interest rate & IV & $\begin{array}{c}0.09 \\
(1.61)\end{array}$ & - & - & 1st lag & - & 37 \\
\hline & Spread with short-term interest rate & IV & $\begin{array}{c}0.00 \\
(0.03)\end{array}$ & - & - & 2nd lag & - & 36 \\
\hline (3) & 10 -year bonds yield & OLS & - & $\begin{array}{c}-0.02 \\
(-5.62)^{\star * \star}\end{array}$ & - & - & -3.73 & 37 \\
\hline$(4)$ & 10 -year bonds yield & OLS & - & - & $\begin{array}{c}-0.02 \\
(-5.27)^{\star \star \star}\end{array}$ & - & -3.74 & 37 \\
\hline \multicolumn{9}{|l|}{ U.S. } \\
\hline$(1)$ & 10 -year bonds yield & OLS & $\begin{array}{c}0.38 \\
(8.12)^{\star \star *}\end{array}$ & - & - & - & -4.04 & 38 \\
\hline (2) & Spread with short-term interest rate & IV & $\begin{array}{c}0.36 \\
(5.87)^{\star * *}\end{array}$ & - & - & 1st lag & - & 37 \\
\hline & Spread with short-term interest rate & IV & $\begin{array}{c}0.20 \\
(1.12)\end{array}$ & - & - & 2nd lag & - & 36 \\
\hline (3) & 10 -year bonds yield & OLS & - & $\begin{array}{c}-0.04 \\
(-1.93)^{\star}\end{array}$ & - & - & -3.33 & 37 \\
\hline$(4)$ & 10 -year bonds yield & OLS & - & - & $\begin{array}{c}-0.04 \\
(-2.17)^{\star \star}\end{array}$ & - & -3.37 & 37 \\
\hline \multicolumn{9}{|l|}{ U.K. } \\
\hline (1) & 10-year bonds yield & OLS & $\begin{array}{c}0.27 \\
(3.73)^{\star \star *}\end{array}$ & - & - & - & -3.34 & 30 \\
\hline$(2)$ & Spread with short-term interest rate & IV & $\begin{array}{c}0.39 \\
(3.73)^{\star * *}\end{array}$ & - & - & 1st lag & - & 29 \\
\hline & Spread with short-term interest rate & IV & $\begin{array}{c}0.38 \\
(2.70)^{\star \star}\end{array}$ & - & - & 2nd lag & - & 28 \\
\hline (3) & 10-year bonds yield & OLS & - & $\begin{array}{c}-0.09 \\
(-1.76)^{*}\end{array}$ & - & - & -2.82 & 29 \\
\hline (4) & 10-year bonds yield & OLS & - & - & $\begin{array}{c}-0.09 \\
(-1.54)\end{array}$ & - & -2.87 & 29 \\
\hline \multicolumn{9}{|c|}{ France } \\
\hline (1) & 10-year bonds yield & OLS & $\begin{array}{c}0.17 \\
(1.94)^{\star}\end{array}$ & - & - & - & -3.12 & 29 \\
\hline$(2)$ & Spread with short-term interest rate & IV & $\begin{array}{c}0.07 \\
(0.32)\end{array}$ & - & - & 1st lag & - & 28 \\
\hline & Spread with short-term interest rate & IV & $\begin{array}{l}0.16 \\
(0.35)\end{array}$ & - & - & 2nd lag & - & 27 \\
\hline (3) & 10-year bonds yield & OLS & - & $\begin{array}{c}-0.09 \\
(-4.67)^{\star * *}\end{array}$ & -0.09 & - & -3.44 & 28 \\
\hline (4) & 10-year bonds yield & OLS & - & - & $(-5.47)^{\star \star \star}$ & - & -3.35 & 28 \\
\hline \multicolumn{9}{|c|}{ Germany } \\
\hline (1) & 10 -year bonds yield & OLS & $\begin{array}{c}0.27 \\
(2.66)^{\star \star}\end{array}$ & - & - & - & -2.53 & 33 \\
\hline$(2)$ & Spread with short-term interest rate & IV & $\begin{array}{c}0.88 \\
(2.22)^{\star *}\end{array}$ & - & - & 1st lag & - & 32 \\
\hline & Spread with short-term interest rate & IV & $\begin{array}{c}3.24 \\
(0.59)\end{array}$ & - & - & 2nd lag & - & 31 \\
\hline (3) & 10-year bonds yield & OLS & - & $\begin{array}{c}-0.05 \\
(-6.15)^{\star \star \star}\end{array}$ & - & - & -3.63 & 32 \\
\hline (4) & 10-year bonds yield & OLS & - & - & -0.07 & - & -3.61 & 32 \\
\hline & & & & & $(-8.08)^{\star \star *}$ & & & \\
\hline
\end{tabular}

$1 /$ When the spread is the dependent variable, the short-term interest rate is not included as an independent variable.

$2 /$ Robust $t$ statistics are reported in parentheses.

$3 /{ }^{* * *},{ }^{* *}$, and * indicate the statistical significance at the 1 percent, 5 percent, and 10 percent, respectively. 
8. That said, other factors specific to Japan, which are not included in the regression analysis, may be contributing to the low sensitivity of JGB yields (IMF, 2009):

- $\quad$ Large pool of household assets. Japan had enjoyed quite high household saving rates (over 10 percent) until around 2000 (Figure I.3), which contributed to a large build-up of household financial assets to help finance public debt.

- $\quad$ Little dependence on external financing and home bias. JGBs have been financed largely by domestic investors (93 percent of holdings as of end-2008) who may be a more stable source of funds than foreigners. Smaller foreign holdings reflect higher home bias in Japan than in other advanced countries (IMF, 2005).

- $\quad$ Existence of large and stable institutional investors. Japan Post Bank (previously the postal savings) had invested $¥ 156$ trillion in JGBs (around 20 percent of the total JGBs) as of September 2008. In addition, the national pension represents a stable investor in JGBs, holding $¥ 82$ trillion as of end-2008.
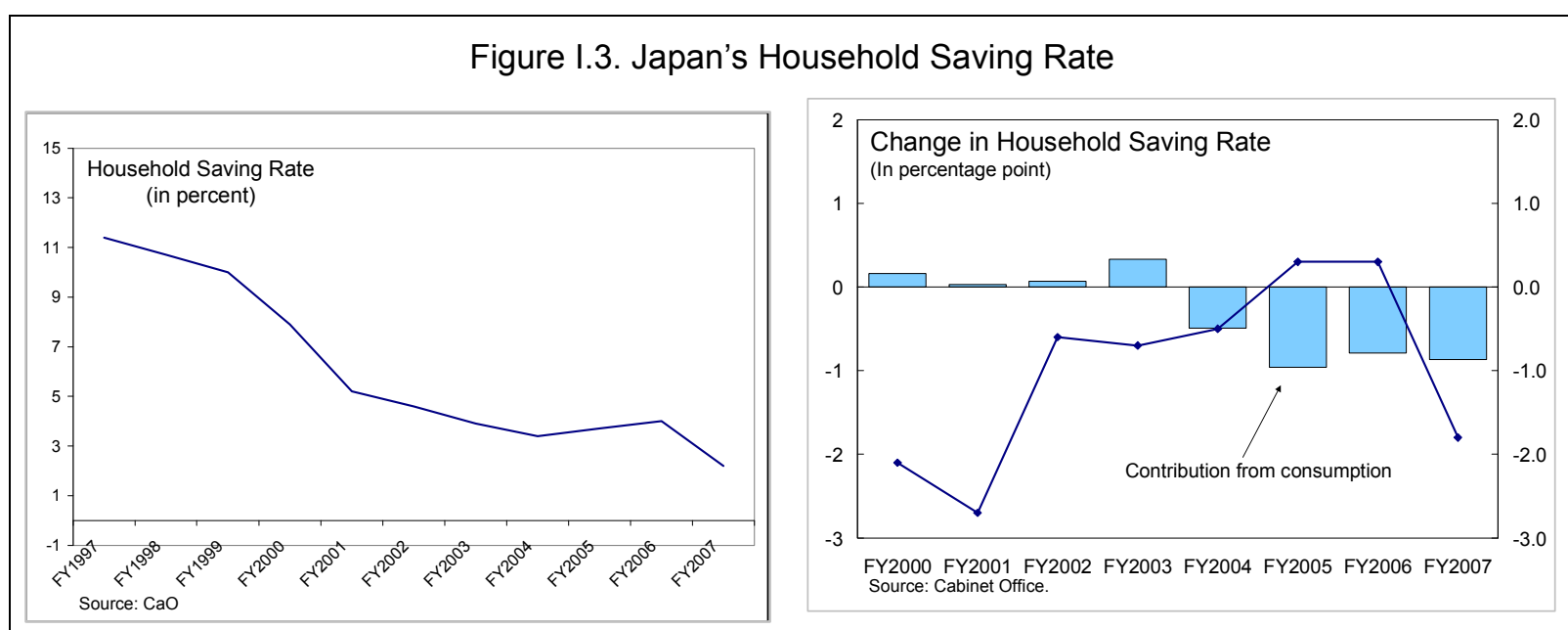

9. Indeed, once the stock of household financial wealth and the share of foreign holdings of JGBs are included as additional controls, the regression coefficient on the net/gross debt turns positive. However, the coefficient on the debt is still relatively small (around 0.01) with a moderate robust t-statistic (at most 1.3). ${ }^{12}$ These results suggest that estimates of the debt impact on the yields could be dampened if household financial wealth and foreign holdings of JGBs are not controlled.

\footnotetext{
${ }^{12}$ The coefficient on the stock of household financial wealth is negative (as predicted) with a large t-statistic (around 3), while that on the share of foreign holdings is close to zero.
} 
Table I.4. Japan: Regression Results

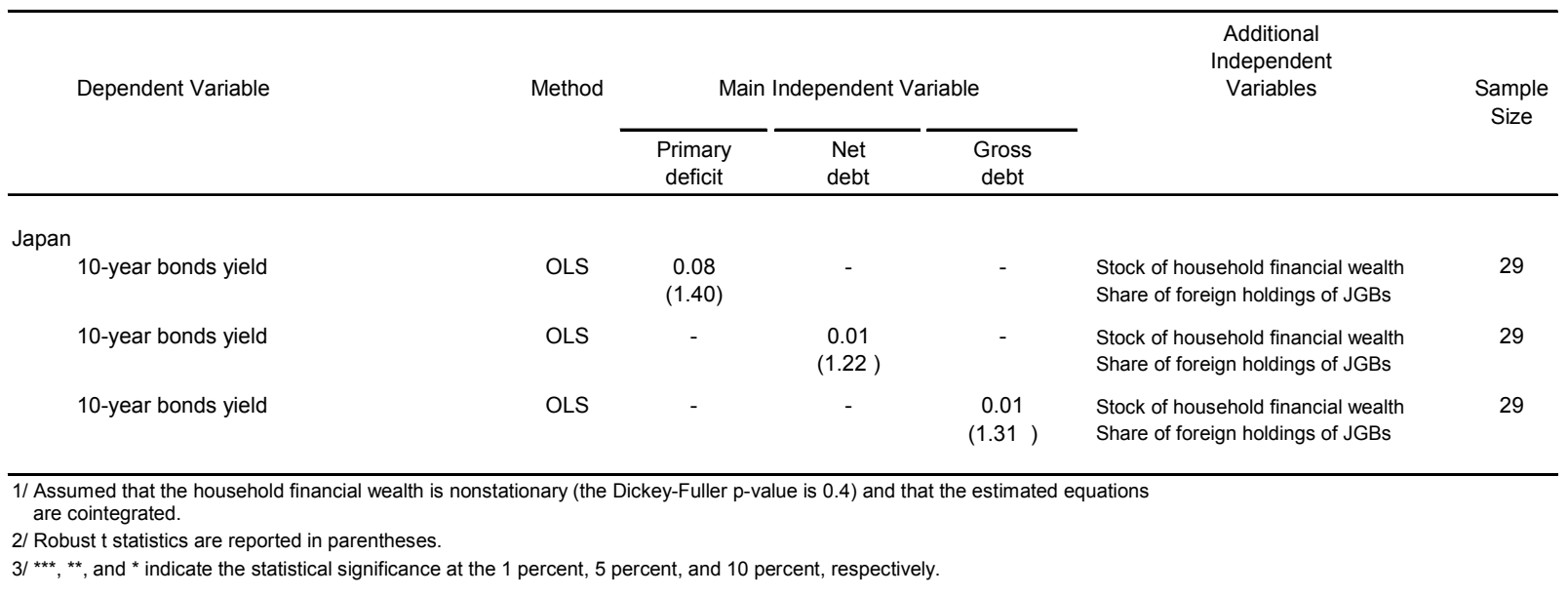

10. In addition, over the past ten years the Fiscal Investment and Loan Program (FILP) and the corporate sector may have been playing a supporting role in creating favorable market conditions. ${ }^{13}$

- $\quad$ As a result of the FILP reform, which aimed to rationalize FILP lending to public agencies, FILP lending has shrunk, forcing these agencies to curtail their projects and rely more on private financing. This has reduced FILP liabilities substantially by around half to about $¥ 200$ trillion (40 percent of GDP) since 2000 . The downsizing has effectively created space for financing other public debt, as the FILP was largely financed by deposits in the postal savings and reserves in the public pension (before the reform). The impact of the downsizing is substantial; despite the the central governement's large and persistent fiscal deficits in the early 2000s, public debt including the FILP has not increased over the past ten years. ${ }^{14}$

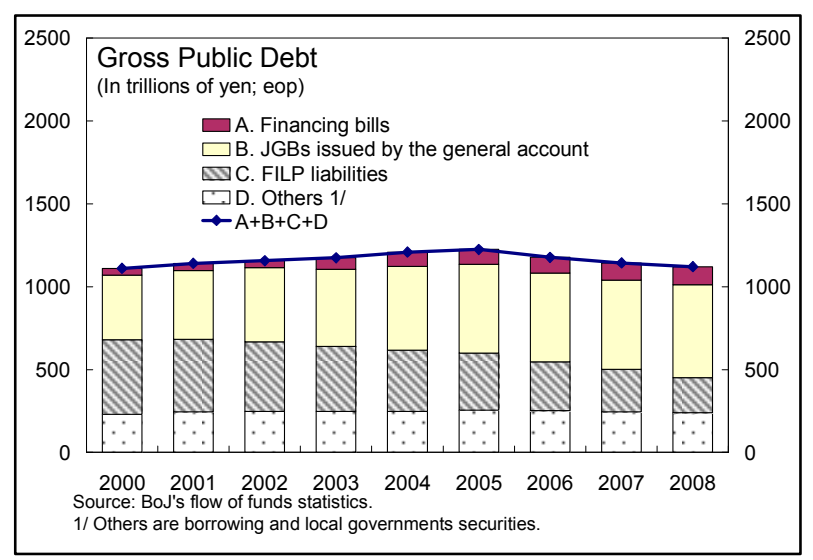

\footnotetext{
${ }^{13}$ Under the FILP, the government provides funds to various government affiliated corporations for implementing public projects, such as infrastructure.

${ }^{14}$ The general government debt on the SNA basis excludes FILP liabilities.
} 
The corporate sector has been recording financial surpluses following its recovery from the crisis in the 1990s. Since the late 1990s, the corporate sector has been providing funds along with the household sector through banks, to help finance the increase in public debt.

\section{Going forward, structural shifts in}

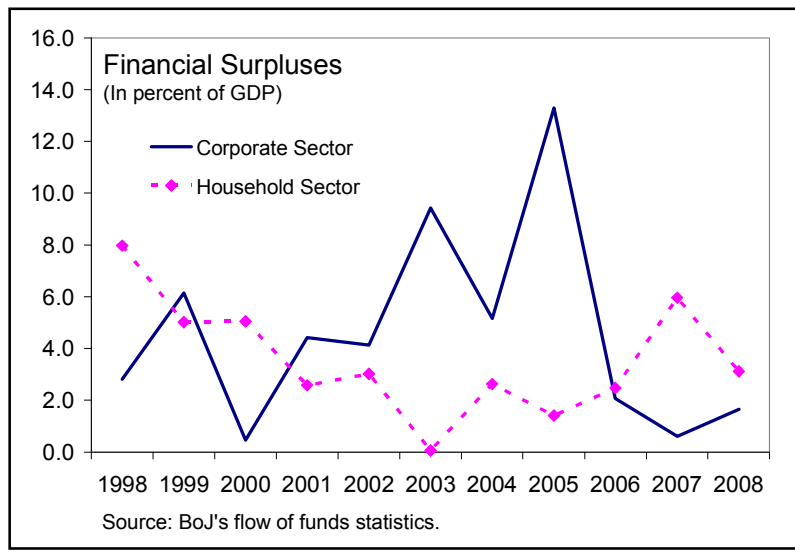

household balance sheets and key market players could affect the absorptive capacity of the JGB market. These shifts may work to weaken some of the factors listed above. As the debt level rises and the market's absorptive capacity declines, the yields could become more sensitive to the debt level as standard theory predicts. There is some empirical evidence consistent with the view that the yields' response to the debt level is nonlinear and becomes significant once the debt exceeds a certain threshold, ${ }^{15}$ although determining such a threshold in the case of Japan is difficult. In this regard, the recent pickup in JGB yields (although relatively limited) following announcements of fiscal stimulus measures might suggest an increased risk premium perceived by market participants. They may also reflect increased roll-over risks for public debt.

\begin{tabular}{|c|c|c|c|c|c|}
\hline & \multicolumn{3}{|c|}{$\begin{array}{l}\text { Table I.5. Share of JGBs Holdings } 1 / \\
\text { (In percent) }\end{array}$} & \multirow[b]{2}{*}{ Dec-07 } & \multirow[b]{2}{*}{ Dec-0\& } \\
\hline & Dec-00 & Dec-05 & Dec-06 & & \\
\hline $\begin{array}{l}\text { Government 2/ } \\
\text { Of which: }\end{array}$ & 23.1 & 15.9 & 14.3 & 13.8 & 13.1 \\
\hline Public Pension & 2.8 & 9.2 & 9.8 & 11.1 & 11.7 \\
\hline Central bank & 11.9 & 14.0 & 11.2 & 9.5 & 8.3 \\
\hline Financial institutions & 55.1 & 59.9 & 62.2 & 62.0 & 64.1 \\
\hline \multicolumn{6}{|l|}{ Of which: } \\
\hline Postal Savings & 7.0 & 18.5 & 20.3 & $\ldots$ & $\ldots$ \\
\hline Banks 3/ & 22.3 & 17.0 & 16.3 & 35.0 & 36.1 \\
\hline Overseas & 5.9 & 4.7 & 5.5 & 7.0 & 6.8 \\
\hline Households & 2.2 & 4.0 & 4.8 & 5.3 & 5.2 \\
\hline Others 4/ & 1.8 & 1.6 & 2.0 & 2.3 & 2.4 \\
\hline Total (in trillions of yen) & 391.2 & 672.1 & 674.6 & 682.4 & 699.6 \\
\hline $\begin{array}{l}\text { Total excluding FILP bonds } \\
\text { (in trillions of yen) }\end{array}$ & 391.2 & 535.8 & 534.8 & 538.2 & 560.4 \\
\hline \multicolumn{6}{|c|}{ Source: BoJ's Flow of Funds statistics. } \\
\hline \multicolumn{6}{|c|}{ 1/ JGBs are the general account bonds and the Fiscal Investment Loan Program (FILP) bonds, and do not include financing bills. } \\
\hline \multicolumn{6}{|c|}{ 2/ Includes the Fiscal Investment and Loan Program (FILP). } \\
\hline \multicolumn{6}{|c|}{ 3/ Includes Japan Post Bank for Dec-07 and Dec-08. } \\
\hline \multicolumn{6}{|c|}{ 4/ Nonfinancial corporations and private nonprofit institutions serving households. } \\
\hline
\end{tabular}

${ }^{15}$ Faini, 2006; Ardagna, Caselli, and Lane, 2004. 


\section{Household sector}

12. A large portion of JGBs is essentially financed by the household sector. While direct holdings of JGBs are only 5 percent of the total outstanding amount, if indirect channels are taken into account, at least around 50 percent of the total JGBs is financed by the household sector mainly through banks (including Japan Post Bank) and pension funds (Figure I.4). ${ }^{16}$

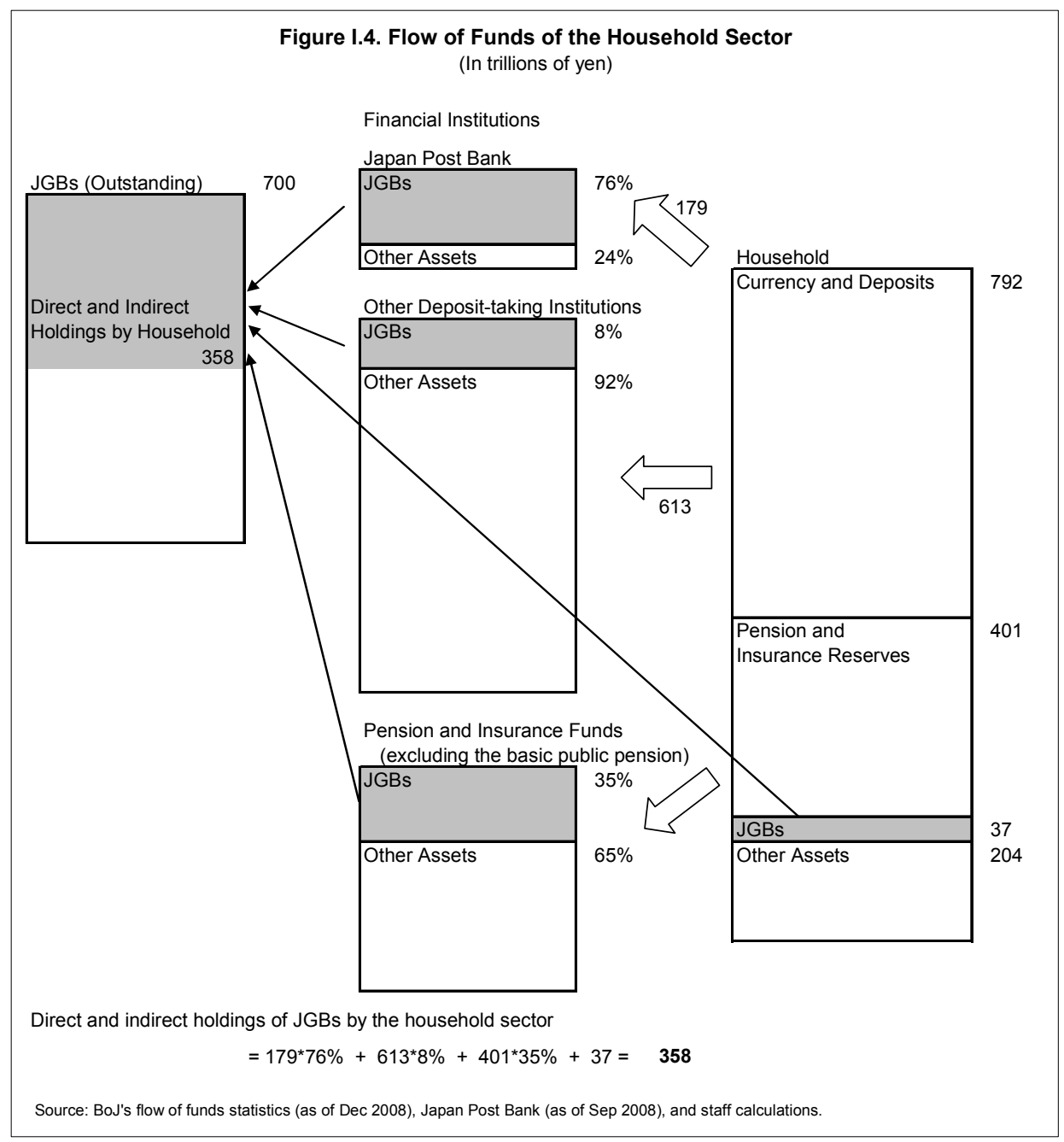

13. Given the dominant role played by the household sector in public debt financing, a declining household saving rate driven by aging could put significant pressure on the market. While there was a slight pickup around 2006, the household saving rate has been on a trend decline (Figure I. 3), consistent with the downward trend in household contributions to financial assets. With population aging, the saving rate is expected to decline further from

\footnotetext{
${ }^{16}$ Other indirect holdings of JGBs by the household sector which are not included in the figure are possible. For example, a part of the JGBs holdings by the nonfinancial sector, whose equities the household sector owns, could be included in them.
} 
the current level (2.2 percent as of FY2007). Indeed, recent data have suggested that there is already some negative impact of the aging process on the saving rate: according to the $\mathrm{CaO}$, contributions to the decline in the household saving rate from rising consumption have been growing since FY2004 (Figure I. 3).

\section{Staff's calculations suggest that} without policy adjustment, the household ability to absorb public debt will continue to shrink toward 2020.

Simulation results indicate that in 2019 gross public debt excluding the FILP could exceed the level of households' financial assets, assuming no further contribution from household savings. Assuming a 2.2 percent of household income - the household saving rate in FY2007contribution to accumulation of financial assets delays this cross-point by two years.

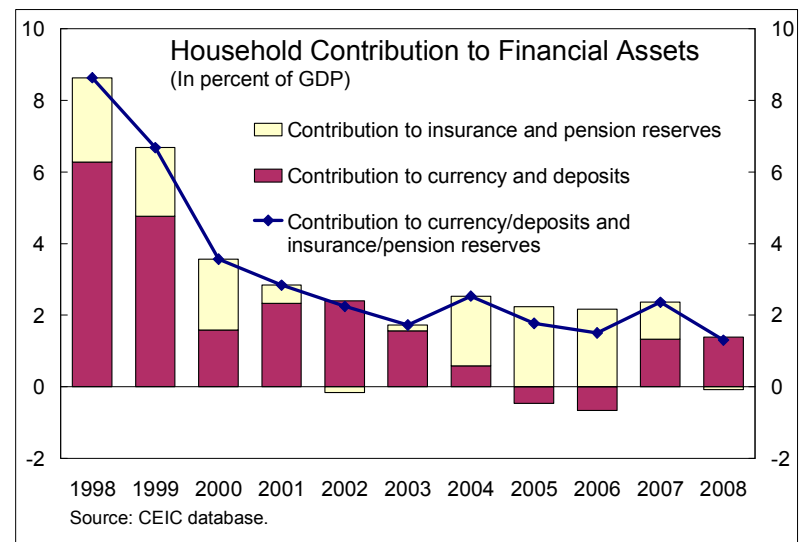
Source: CEIC database.

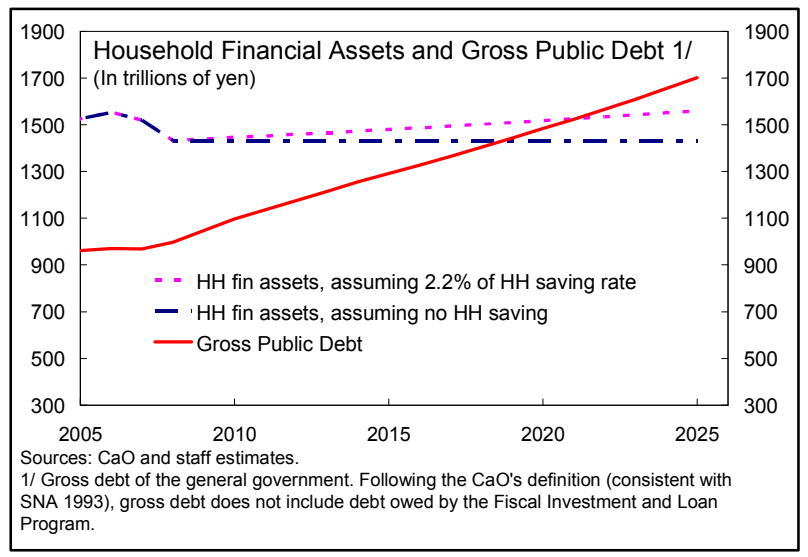
These estimates also imply that by 2020 gross public debt could increase by around $¥ 350$ 400 trillion (70-80 percent of 2008 GDP) relative to household financial assets. The results indicate that domestic financing will likely become more difficult toward 2020, while other sources of funding are available including from overseas. Under current trends, funding may need to rely more on foreign sources to maintain stability.

\section{Financial sector}

\section{At the same time, financial reforms that have given institutional investors more} flexibility could also hinder the market capacity. Changes in the investment behavior by the Government Pension Investment Fund may affect the JGB market beyond a decline in contributions arising naturally from aging. The pension fund no longer has an obligation to purchase JGBs, which the FILP issues (FILP bonds), and is now looking to expand its investment in risky assets. ${ }^{17}$ Similarly, the Japan Post Bank (previously the postal savings) is now allowed to expand its investment in other assets. Given the huge size of assets held by these institutions, even a moderate shift from JGBs to other assets could have a significant

\footnotetext{
${ }^{17}$ As a result of the FILP reform in 2001, the postal savings and the public pension funds stopped lending for public projects through the FILP. During the transitional period after the reform, the postal savings and the national pension funds were required to accept government bonds which the FILP issued.
} 
impact on the market ( 10 percent shift would amount to $¥ 20-30$ trillion (4-6 percent of GDP)).

\section{A decline in the home bias particularly among private financial institutions} could also affect the market's absorptive capacity in the medium-term. In the current global financial turmoil, domestic (institutional) investors may have shifted to safe domestic assets including JGBs, seeking a safe haven. However, once financial market conditions recover, appetite for risky foreign assets could return.

\section{The Bank of Japan (BoJ), which currently holds} about 8 percent of total JGBs, would likely continue to play an important role in market stability. Its recent decision to increase monthly purchase of JGBs appears to have helped to stabilize market conditions.

\section{Other domestic sectors}

\begin{tabular}{|lc|}
\hline \multicolumn{2}{c|}{$\begin{array}{c}\text { BoJ's Monthly Outright Purchase of } \\
\text { Long-term JGBs } \\
\text { (In trillions of yen) }\end{array}$} \\
\hline Before Aug. 2001- & 0.4 \\
Aug. 2001- & 0.6 \\
Dec. 2001- & 0.8 \\
Feb. 2002- & 1.0 \\
Oct. 2002- & 1.2 \\
Jan. 2008- & 1.4 \\
Mar. 2009- & 1.8 \\
\hline Source: BoJ. \\
\hline
\end{tabular}

18. The role of the FILP and the corporate sector to facilitate smooth financing of public debt may also diminish. The room for further downsing of the FILP has been curtailed. At the same time, crisis related lending needs financed by the FILP have increased. The financial surpluses in the corporate sector have also declined in recent years (around 1 percent of GDP in both 2007 and 2008), and may not rebound so soon in the current recession.

\section{Foreign sector}

19. Given the small foreign holdings of JGBs, shifts in foreign investor behavior are unlikely to have a significant impact for the time being. The smaller increase in JGB yields and lower volatility relative to other advance economies might also reflect the smaller foreign holdings of JGBs. That said, in the near-term, the possibility of a negative impact on the JGB market of sharp increases in sovereign bond issuances across the world (e.g., through crowding-out of

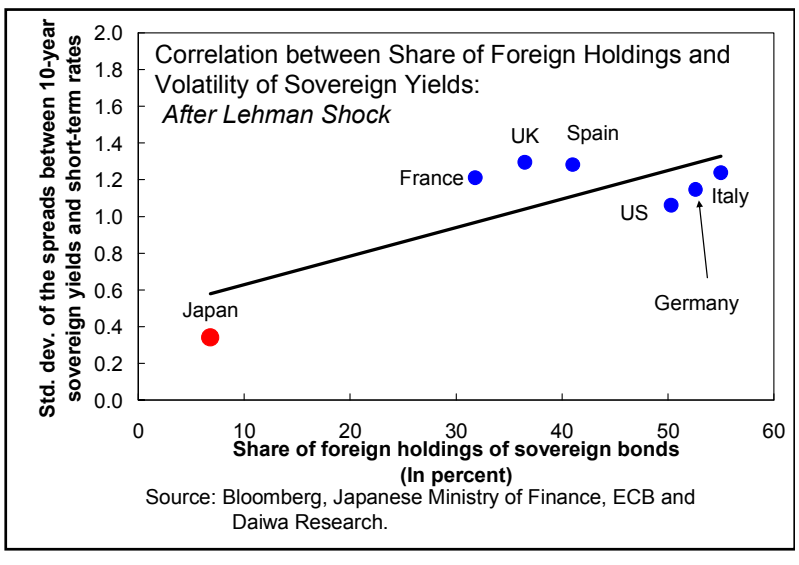
JGBs by other sovereign debt) cannot be ruled out.

\section{Policy Issues}

20. Going forward, the gross public financing requirement is likely to be substantial. The gross financing need is estimated to reach 50 percent of GDP in 2009 (including rollover of financing bills), and is projected to rise further reflecting a sharp increase in debt. To 
ensure the smooth refinancing of this debt, both medium-term and short-term responses are necessary.

- $\quad$ Medium-term fiscal framework. Over the medium-term, it is critical to establish a credible framework for ensuring fiscal sustainability. A key element in the framework is a clear timetable for comprehensive tax and expenditure reforms once the economy recovers.

- $\quad$ Public debt management. To stabilize yields and ensure stable absorption of debt by the market, the timing of debt issuance and maturity structure should continue to be carefully determined. The authorities' ongoing efforts to communicate clearly with market participants also remain critical in this respect.

\section{Conclusion}

21. Historically, Japan's public debt has been financed in a fairly smooth manner. The large pool of household savings and the stable domestic institutional investor base appear to have contributed to this successful experience. However, Japan is already undergoing rapid population aging, which will likely limit the market's future absorptive capacity of public debt. In addition, structural shifts in institutional investors could also serve to reduce market demand. To maintain market stability, sound public debt management will be critical in the near term, but over the longer term progress fiscal consolidation through comprehensive revenue and expenditure reforms will be required. 


\section{Appendix I.1}

1. This appendix details stationarity assumptions on time series data used for the baseline regressions in the main text.

2. The results of Dickey-Fuller tests are reported in the table. A unit root test is clearly not rejected for the 10-year government bond yield and the general government net/gross debt (high p-values across countries). The test results for the short-term interest rate are more ambiguous, but all of these four variables are assumed to be nonstationary.

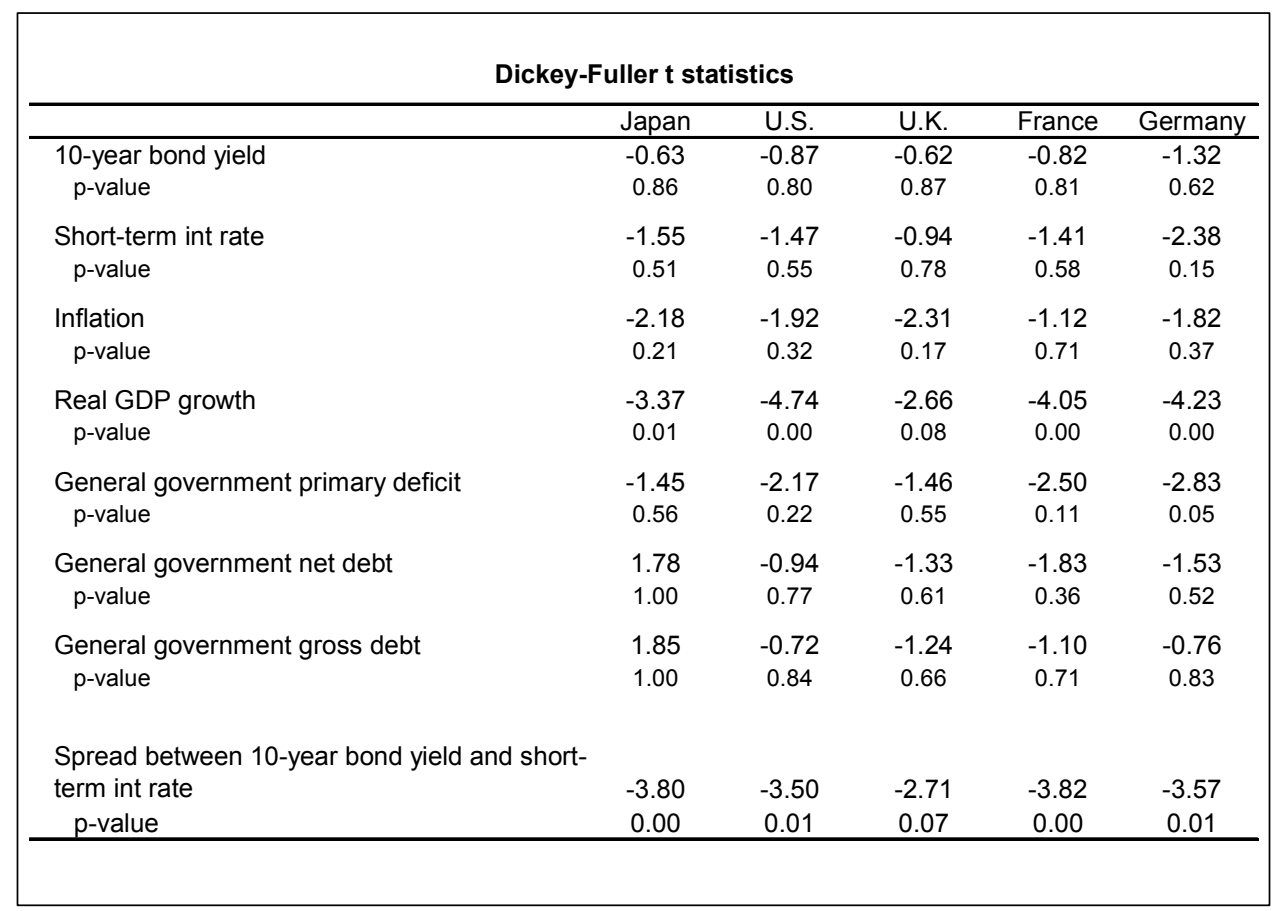

3. Further assumptions by regression are as follows:

\begin{tabular}{|lll|}
\hline \multicolumn{1}{c}{ Dependent variable } & Main independent variable & \multicolumn{1}{c|}{ Assumption } \\
\hline (1) 10-year bond yield & $\begin{array}{l}\text { General government primary } \\
\text { deficit }\end{array}$ & $\begin{array}{l}\text { The 10-year bond yield and the short- } \\
\text { term interest rate are cointegrated. }\end{array}$ \\
(2) Spread with short-term interest rate & $\begin{array}{l}\text { General government primary } \\
\text { deficit }\end{array}$ & $\begin{array}{l}\text { All the variables (spread, inflation, real } \\
\text { GDP growth, and general government } \\
\text { primary deficit) are stationary. }\end{array}$ \\
& $\begin{array}{l}\text { General government net } \\
\text { debt }\end{array}$ & $\begin{array}{l}\text { The 10-year bond yield, the short-term } \\
\text { interest rate, and the net debt are } \\
\text { cointegrated. }\end{array}$ \\
(3) 10-year bond yield & General government gross \\
debt 10 -year bond yield & $\begin{array}{l}\text { The 10-year bond yield, the short-term } \\
\text { interest rate, and the gross debt are } \\
\text { cointegrated. }\end{array}$ \\
\hline
\end{tabular}




\section{References}

Ardagna, Silvia, Francesco Caselli, and Timothy Lane, 2004, "Fiscal Discipline and the Cost of Public Debt Service: Some Estimates from OECD Countries,” NBER Working Paper No. 10788.

Caporale G., and G. Williams, 2002, "Long-term Nominal Interest Rates and Domestic Fundamentals," Review of Financial Economics, Vol. 11.

Edison, Hali, 2005, "Household Savings in Japan," in Japan-Selected Issues, IMF Country Report No. 05/272.

Faini, Riccardo, 2006, "Fiscal Policy and Interest Rates in Europe," Economic Policy.

Elmendorf, Douglas W. and N. Gregory Mankiw, 1999 "Government Debt." In John B. Taylor and Michael Woodford (eds.), Handbook of Macroeconomics, Amsterdam: Elsevier Science, Chapter 25.

Engen, Eric and R. Glenn Hubbard, "Federal Government Debts and Interest Rates," NBER Working Paper No. 10681.

Feldstein, Martin, 1986, "Budget Deficits, Tax rules, and Real Interest Rates," NBER Working Paper Series, No. 1970.

Gale, William G., and Peter Orszag, 2003, "Economic Effects of Sustained Budget Deficits," National Tax Journal Vol. 56, No. 3 (September), pp. 463-485.

International Monetary Fund, 2009, "Companion Paper-The State of Public Finances: Outlook and Medium-Term Policies After the 2008 Crisis"

International Monetary Fund, 2006, "Awash with Cash: Why Are Corporate Savings So High," World Economic Outlook, Chapter IV, pp. 135-159 April.

Laubach, Thomas, 2003, "New Evidence on the Interest Rate Effects of Budget Deficits and Debt," Finance and Economics Discussion Series, Divisions of Research \& Statistics and Monetary Affairs, (Washington: Federal Reserve Board).

Walker, Chris, 2005, "Home Bias in Japan," in Japan—Selected Issues, IMF Country Report No. $05 / 272$. 


\section{JAPAN AND THE GLOBAL FinANCIAL SYSTEM: SPILLOVERS AND SYSTEMIC LINKAGES ${ }^{1}$}

\section{A. Introduction}

1. The global crisis has underscored the need to assess potentially systemic linkages across financial systems. The globalization and increased complexity of financial services has contributed to stronger linkages between international financial institutions. While these trends can contribute to economic growth by smoothing credit allocation and diversifying risk, they can also exacerbate the transmission of shocks. Indeed, the current crisis has demonstrated that systemic linkages can stem not just from solvency concerns, but also from liquidity squeezes and other stress events, and can quickly spillover across international financial systems.

\section{This chapter uses two complementary approaches to assess risks from financial} linkages between Japan's financial system and the rest of the world. The analysis is focused on the banking system - which dominates financial intermediation in Japan - and on its linkages with other advanced economies, which account for the bulk of Japan's overseas exposures. The first approach relies on network analysis, which tracks the spillover effects on banking systems of a credit event or liquidity squeeze through linkages in the interbank market. The second approach is based on the Co-Risk model, which uses market data to explore perceptions of direct and indirect linkages among financial institutions during stress events.

\section{This work is part of an ongoing effort to further develop surveillance tools for} cross-border analysis. The approaches used apply the work featured in Chapter 2 of the April 2009 GFSR. Such tools provide useful metrics for regulators to assess which systems and institutions could be a source of contagion, while highlighting potential spillover paths through the international financial system.

\section{B. Cross-Border Financial Linkages in Japan: Recent Developments}

4. Japan has played an active role in the integration of global financial markets. These connections are reflected in cross-border claims of Japanese banks, which have expanded significantly in recent years. While overseas exposures remain relatively low compared with U.S. and European banks, Japanese banks have been re-establishing international

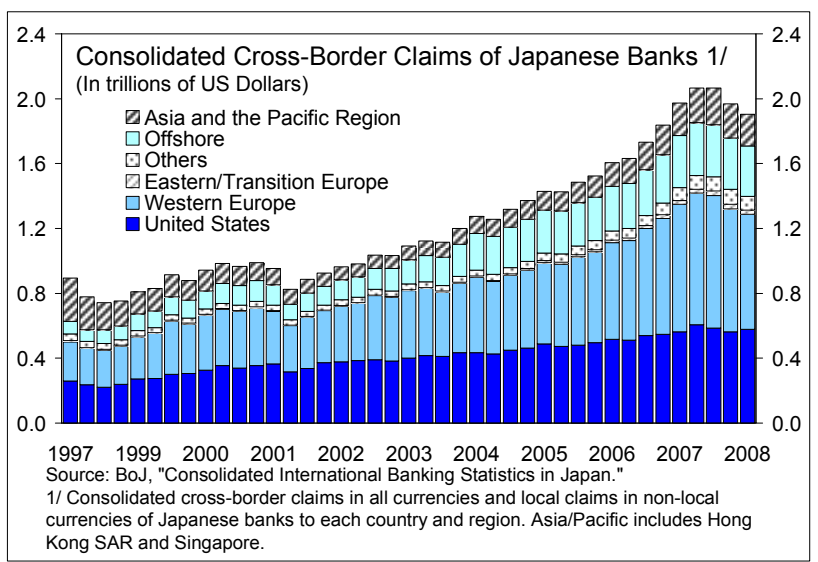

${ }^{1}$ Prepared by Marco Espinosa-Vega, Juan Solé, and Murtaza Syed. 
presence following the banking crisis of the late 1990s and early 2000s. Since mid-2002, Japanese banks' cross-border claims have more than doubled from around $\$ 800$ billion to nearly $\$ 2$ trillion, with exposures to Western Europe accounting for more than 40 percent of the increase. Overall, advanced economies account for more than two-thirds of Japanese banks' total overseas claims. By contrast, direct exposure to Eastern Europe- which has emerged as a potential flash point amid the current crisis - is very limited.

\section{While also expanding in recent years, exposure to Asia remains relatively}

modest. Prior to the 1997-98 Asian crisis, Japanese exposures to Asia were similar to those of other regions. Subsequently, Japanese banks significantly cut back on their Asian operations in the wake of Japan's banking crisis. Over the last six years, however, Japanese banks have also re-engaged with the rest of the region, with lending picking up sharply, in particular to Australia, China, India, New Zealand and Korea. ${ }^{2}$

Nevertheless, overseas claims of Japanese banks on the rest of Asia (including Hong Kong SAR and Singapore) are still only around one-third to one-quarter of those on Western Europe and the United States. As a result, risks of financial spillovers to and from the rest of the region appear low at present, and are likely to be much less significant than those associated with advanced economies outside Asia.

\section{Cross-border bank exposures}

have fallen somewhat, over the last year reflecting factors such as unwinding yen carry trades and a retrenchment of Japanese banks' lending abroad. Various proxies for overseas yen funding - including inter office accounts of foreign banks' activities, foreign bank borrowing in Japanese money markets, foreign exchange margin trading and short-yen positions of non-commercial traders-

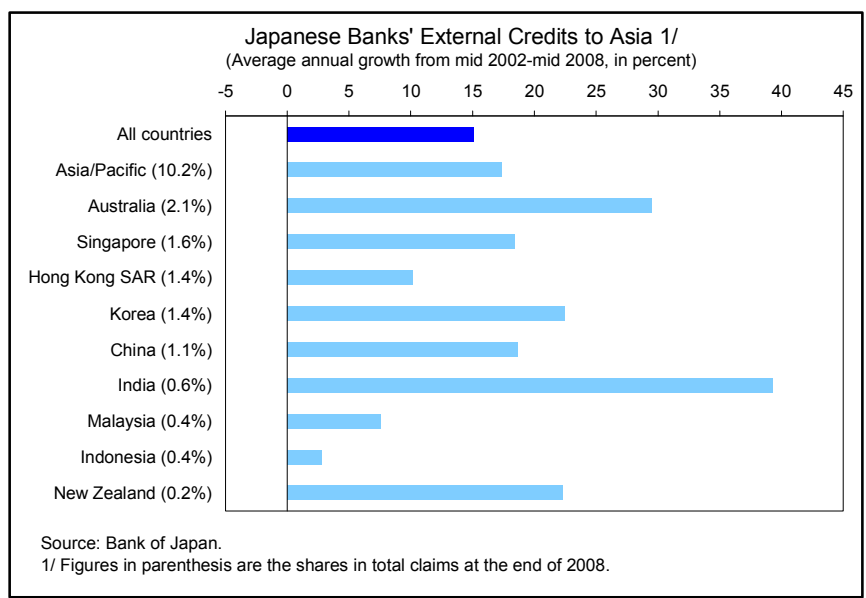

Source: Bank of Japan

Source: Bank of Japan.
1/ Figures in parenthesis are the shares in total claims at the end of 2008 . suggest that carry trade positions have been unwinding as interest rate differentials have narrowed and exchange rate volatility has increased. Japanese banks' overseas lending,

${ }^{2}$ See Chapter IV of the 2006 Selected Issues paper for more details. 
which increased by nearly 20 percent (y/y) last June, has fallen significantly since the escalation of the global crisis, contracting by $3 \frac{1}{2}$ percent $(y / y)$ in December.

7. However, the strains in Japanese financial markets during the current global crisis highlight the importance of cross-border spillovers, and suggest the need to closely monitor cross-border linkages and vulnerabilities. While direct bank-to-bank linkages remain relatively low, Japan is closely integrated with global financial markets, as highlighted by the significant strains induced by the collapse of Lehman Brothers last Fall. These events highlight the need for a closer monitoring of Japanese cross-country exposures. In the same vein, regulators overseas should monitor risks that their financial systems may face from other economies, including Japan. Motivated by this need and the dominance of Western Europe and the United States in Japanese banks' overseas exposure, the rest of this chapter examines some key questions that are likely to be of interest to policymakers and regulators both in and outside Japan, namely:

- Assessment of spillover risks and systemic linkages. How vulnerable is the Japanese financial system to distress in overseas financial institutions, and vice versa?

- Tracking impacts across economies. What are the potential contagion paths, including indirect effects?

- Dynamics. How have these systemic linkages changed since the onset of the crisis, particularly as yen carry trades have been unwinding?

\section{Network Analysis: Assessing Systemic Linkages using Banking Exposures ${ }^{3}$}

8. Methodologies to assess potentially systemic institutions include those that rely primarily on institutional data, such as network analysis, and those that rely primarily on market data, such as the Co-Risk model which is briefly discussed in the next section. Network analysis relies primarily on institutional data. The basis for this analysis is the construction of a matrix of gross institutional exposures (domestic and cross-country). Researchers then track the network spillovers resulting from hypothetical credit events to specific institutions. Recent important extensions include the analysis of liquidity (or funding) events as in Chan-Lau et al. (2009 a, b). Most of the network literature has focused on the interbank credit market because interbank loans represent a large fraction of banks' balance sheets in many countries (Upper, 2007).

9. Network analysis is a potentially powerful surveillance tool. Information extracted from the analysis of spillover effects can be used to produce and track several vulnerability indicators such as a hazard rate (or the number of times an institution would fail in the face of

\footnotetext{
${ }^{3}$ The analysis presented in this section relies on a methodology developed in Chan-Lau et al. (2009 a,b).
} 
alternative stress events), the path and rounds of contagion resulting from alternative "trigger" institutions and the capital impairment (or the percentage of the pre-event capital an institution would lose once all the contagion rounds are accounted for). In this section, we perform some comparative network spillover analysis for Japan.

\section{We use network analysis to track hypothetical network spillovers for the} Japanese banking system arising from severe credit and liquidity events. The exercise relies on bilateral consolidated cross-border bank exposures for a sub-sample of sixteen BIS reporting countries for three dates: December 2007, March 2008 and December 2008.

\section{Specifically, two scenarios are considered-a hypothetical severe credit shock and a combination of this credit plus a funding shock.}

- Severe credit event. The first scenario tracks the domino effects triggered by the individual default of each country's cross-border interbank claims. It is assumed that a country's banking sector losses are fully absorbed by its capital, and a country's banking sector is said to fail when its aggregate capital is not sufficient to fully cover the losses induced by the default on its cross-border interbank claims.

- Severe credit plus liquidity event. The second scenario consists of analyzing the case where the failure of a banking system also induces a liquidity squeeze, forcing a reduction in other banking sectors, balance sheets and, consequently, a fire sale of assets.

Although these hypothetical analyses may be extreme and highly unlikely, they help to illustrate systemic interconnections.

\section{The Japanese banking system is} one of the most resilient in the sample. We find that:

- As for most countries in the sample, the combination of a credit and liquidity events raises the vulnerability of the Japanese banking system.

- However, Japan is much less exposed than other countries. For example, in March 2008, only a credit event triggered by the U.S., would have fully depleted the capital of the Japanese banking sector (Table II.1). If this credit event induces a generalized liquidity squeeze, a default in both the U.S. and the U.K.'s cross-country
Table II.1. Spillovers to Japan: Credit Shock

\begin{tabular}{lccc}
\hline Trigger Country: & Dec-07 & Mar-08 & Dec-08 \\
\hline & Impairment in percent of initial capita \\
Australia & -5.9 & -6.1 & -2.9 \\
Austria & -0.8 & -0.9 & -0.4 \\
Belgium & -3.4 & -2.6 & -1.3 \\
Canada & -4.6 & -4.6 & -2.4 \\
France & -11.1 & -10.9 & -5.5 \\
Germany & -13.8 & -16.4 & -8.7 \\
Ireland & -4.1 & -4.1 & -1.7 \\
Italy & -5.1 & -5.6 & -2.6 \\
Netherlands & -9.0 & -9.0 & -4.2 \\
Portugal & -0.3 & -0.3 & -0.2 \\
Spain & -2.9 & -3.3 & -1.4 \\
Sweden & -1.4 & -1.4 & -0.7 \\
Switzerland & -1.7 & -2.0 & -1.2 \\
United Kingdom & -67.9 & -63.3 & -34.0 \\
United States & Fully impaired & -84.3 \\
\hline
\end{tabular}

Source: IMF staff calculations. 
interbank exposures would have completely depleted Japanese bank capital (Table II.2).

- The magnitude of the impact of these shocks on the Japanese banking system is also relatively low compared to the other economies in our sample. In addition to the recent decrease in their gross exposures, this perhaps reflects an increase in diversification of Japanese banks' activities globally (Table II.3).

- Interestingly, when measured by capital impairment, the vulnerability of the Japanese banking sector to both shocks has generally decreased from its March 2008 peak.
Table II.2. Spillovers to Japan: Credit and Funding Schock

\begin{tabular}{lcrr}
\hline Trigger Country: & Dec-07 & Mar-08 & Dec-08 \\
\hline & Impairment in percent of initial capita \\
Australia & -6.0 & -6.1 & -2.9 \\
Austria & -0.8 & -1.0 & -0.4 \\
Belgium & -3.5 & -2.7 & -4.8 \\
Canada & -4.7 & -4.8 & -2.5 \\
France & -16.9 & -38.2 & -14.5 \\
Germany & -18.0 & -20.0 & -33.0 \\
Ireland & -4.5 & -4.9 & -2.2 \\
Italy & -5.3 & -5.8 & -2.6 \\
Netherlands & -11.0 & -11.1 & -4.8 \\
Portugal & -0.3 & -0.3 & -0.2 \\
Spain & -2.9 & -3.3 & -1.4 \\
Sweden & -1.4 & -1.5 & -0.7 \\
Switzerland & -7.1 & -7.7 & -3.5 \\
United Kingdom & Fully impaired & -49.5 \\
United States & Fully impaired & -97.5 \\
\hline
\end{tabular}

Source: IMF staff calculations.

- Overall, network analysis suggests that the Japanese banking system is highly resilient and that risks to external stability arising from cross-border banking spillovers to Japan have fallen over the last year.

\section{The current crisis has also highlighted the need to analyze the full implications} of stress events, beyond the "point of impact" and including indirect effects. For example, a combined credit and liquidity event triggered by a hypothetical default on German banks' cross-country interbank liabilities, would end up inducing a 33 percent capital loss for the Japanese banking sector after taking into account the full set of domino effects (Table II.4). This is significantly higher than the initial 9.2 percent loss induced "on impact." Similarly, the trigger country may not necessarily inflict the highest degree of capital losses to Japan. In this example, France would have induced a higher degree of capital losses (9.7 percent of the original) for the Japanese banking sector.

\section{Potential spillovers from Japan to the rest of the world also appear relatively}

limited at present. The failure of the Japanese banking system would not trigger the failure of any other banking system, but would lead to significant capital losses in Switzerland, 
Table II.3. Full Sample: Impacts of Credit and Funding Shock (December 2008)

\begin{tabular}{|c|c|c|c|c|c|c|c|c|c|c|c|c|c|c|c|c|}
\hline & Australia & Austria & Belgium & Canada & France & Germany & Ireland & Italy & \multicolumn{2}{|c|}{ Japan Vetherlands } & Portugal & Spain & \multicolumn{2}{|c|}{ Sweden Switzerland } & U.K. & U.S. \\
\hline & \multicolumn{16}{|c|}{ (Impairment in percent of initial capital) } \\
\hline \multicolumn{17}{|l|}{ Trigger Country: } \\
\hline Australia & & -1.9 & -7.3 & 0.0 & -7.0 & -7.2 & -4.6 & -0.2 & -2.9 & -39.9 & -0.7 & -0.7 & -4.4 & -9.8 & -8.3 & -1.7 \\
\hline Austria & -1.8 & & -8.1 & -0.2 & -3.8 & -17.5 & -4.8 & -25.7 & -0.4 & -7.9 & -1.9 & -1.1 & -3.5 & -6.9 & -1.2 & -0.4 \\
\hline Belgium & -36.2 & -18.1 & & -3.3 & -46.8 & -41.7 & -46.0 & -13.4 & -4.8 & Full & -22.7 & -18.0 & -26.0 & -33.3 & -16.1 & -7.3 \\
\hline Canada & 0.0 & -1.6 & -6.7 & & -3.8 & -5.9 & -7.1 & -0.4 & -2.5 & -22.8 & -0.3 & -0.5 & -3.5 & -11.6 & -5.6 & -6.4 \\
\hline France & -61.7 & -32.3 & Full & -4.4 & & -82.6 & -79.0 & -49.3 & -14.5 & Full & -44.0 & -38.6 & -47.7 & -76.3 & -37.5 & -17.2 \\
\hline Germany & -95.9 & Full & Full & -8.5 & Full & & Full & Full & -33.0 & Full & -99.3 & -83.7 & Full & Full & -86.0 & -40.0 \\
\hline Ireland & -2.6 & -5.3 & -90.3 & -0.5 & -13.1 & -30.9 & & -12.6 & -2.2 & -24.1 & -15.5 & -5.0 & -11.7 & -11.7 & -15.3 & -2.4 \\
\hline Italy & -0.5 & -49.3 & -48.7 & -0.1 & -70.1 & -46.1 & -43.5 & & -2.6 & -42.0 & -6.6 & -11.0 & -6.7 & -9.2 & -5.4 & -1.2 \\
\hline Japan & -18.7 & -2.0 & -12.1 & -2.5 & -36.9 & -16.5 & -21.9 & -2.9 & & -24.7 & -1.3 & -1.8 & -7.6 & -59.5 & -9.9 & -12.2 \\
\hline Netherlands & -36.2 & -18.1 & Full & -3.3 & -46.8 & -41.7 & -46.0 & -13.4 & -4.8 & & -22.7 & -18.0 & -26.0 & -33.3 & -16.1 & -7.3 \\
\hline Portugal & -0.2 & -1.9 & -8.7 & 0.0 & -4.6 & -6.6 & -5.8 & -1.2 & -0.2 & -8.2 & & -16.6 & -1.3 & -1.5 & -1.3 & -0.1 \\
\hline Spain & -1.3 & -6.6 & -46.3 & -0.1 & -29.6 & -38.2 & -23.0 & -8.0 & -1.4 & -73.5 & -68.8 & & -11.6 & -7.7 & -14.1 & -2.4 \\
\hline Sweden & -1.4 & -1.7 & -4.2 & -0.2 & -2.7 & -8.9 & -4.7 & -0.5 & -0.7 & -6.0 & -1.3 & -0.9 & & -5.1 & -1.6 & -0.7 \\
\hline Switzerland & -10.0 & -10.9 & -19.3 & -1.1 & -10.8 & -13.0 & -13.1 & -2.8 & -3.5 & -18.9 & -3.8 & -1.9 & -12.6 & & -7.0 & -9.0 \\
\hline United Kingdom & Full & Full & Full & -20.4 & Full & Full & Full & Full & -49.5 & Full & Full & Full & Full & Full & & -64.8 \\
\hline United States & Full & Full & Full & -79.1 & Full & Full & Full & Full & -97.5 & Full & Full & Full & Full & Full & Full & \\
\hline
\end{tabular}

Source: IMF staff calculations. 
Table II.4. Spillovers to Japan: Contagion Paths from Credit and Funding Shock

(December 2008)

\begin{tabular}{|c|c|c|c|}
\hline Trigger Country & $\begin{array}{l}\text { Affected } \\
\text { Countries }\end{array}$ & $\begin{array}{l}\text { Contribution to Final Capital Impairment } \\
\text { (in percent of initial capital) }\end{array}$ & $\begin{array}{c}\text { Japan's Final Capital } \\
\text { Impairment (in percent of initial } \\
\text { capital) }\end{array}$ \\
\hline \multirow[t]{3}{*}{ France } & France & -9.7 & \multirow{3}{*}{-14.5} \\
\hline & Belgium & -1.4 & \\
\hline & Netherlands & -3.4 & \\
\hline \multirow[t]{9}{*}{ Germany } & Germany & -9.2 & \multirow{9}{*}{-33.0} \\
\hline & Netherlands & -3.4 & \\
\hline & Sweden & -0.7 & \\
\hline & Belgium & -1.4 & \\
\hline & Ireland & -2.2 & \\
\hline & France & -9.7 & \\
\hline & Austria & -0.4 & \\
\hline & Italy & -2.6 & \\
\hline & Switzerland & -3.5 & \\
\hline \multirow[t]{13}{*}{ United Kingdom } & United Kingdom & -12.0 & \multirow{13}{*}{-49.5} \\
\hline & Australia & -2.9 & \\
\hline & Belgium & -1.4 & \\
\hline & Ireland & -2.2 & \\
\hline & Netherlands & -3.4 & \\
\hline & Switzerland & -3.5 & \\
\hline & France & -9.7 & \\
\hline & Germany & -9.2 & \\
\hline & Sweden & -0.7 & \\
\hline & Austria & -0.4 & \\
\hline & Italy & -2.6 & \\
\hline & Portugal & -0.2 & \\
\hline & Spain & -1.4 & \\
\hline \multirow[t]{14}{*}{ United States } & United States & -48.0 & \multirow{14}{*}{-97.5} \\
\hline & Belgium & -1.4 & \\
\hline & France & -9.7 & \\
\hline & Netherlands & -3.4 & \\
\hline & Switzerland & -3.5 & \\
\hline & Australia & -2.9 & \\
\hline & Germany & -9.2 & \\
\hline & Ireland & -2.2 & \\
\hline & Sweden & -0.7 & \\
\hline & UK & -12.0 & \\
\hline & Austria & -0.4 & \\
\hline & Italy & -2.6 & \\
\hline & Portugal & -0.2 & \\
\hline & Spain & -1.4 & \\
\hline
\end{tabular}

Source: IMF staff calculations. 
France, Netherlands, Ireland, and Australia (Table II.5). By contrast, spillovers from Japan to the German, U.K. and U.S. banking systems are notably smaller than their impacts on the Japanese banking system, e.g., while the failure of the Japanese banking system would lead to a 16.5 percent decline in the capital of the German banking system, the impact of a hypothetical failure of the German banking system would impose a higher burden on Japan (depleting banking system capital by as much as 33 percent, as shown in Table II.2). Notably, while the spillover impact on the United States is seemingly modest and nowhere close to full impairment, the Japanese banking system has the fourth largest impact on the U.S. banking system, after the United Kingdom, France and Germany (Table II.3).

\section{The Co-Risk Model: Market Perceptions of Spillovers ${ }^{21}$}

\section{Notwithstanding the usefulness of network analysis to assess potentially systemic} financial linkages, it is important to supplement it with alternative methodologies. In addition to network interconnections through interbank exposures, there are likely to be other linkages between financial institutions arising from exposure to common risks factors, such as the adoption of similar business models (e.g., similar risk management systems or portfolio holdings), common accounting practices, market perceptions of financial institutions' coincidence of fortunes, and so on. One method of extracting this information focuses on tracking market perceptions of how the credit risk of one institution affects other institutions' credit risk (in particular, see Brunnermeier et al. (2009)).

\section{A major appeal of these type of methodologies is their reliance on high} frequency, publicly available data. The data includes institutions' CDS spreads, Moody's KMV EDFs, corporate bond spreads, distance-to-default measures or the VaR of their trading portfolio. Under efficient markets, co-movement of these variables should convey information about both direct and indirect linkages across financial institutions. ${ }^{22}$

\footnotetext{
${ }^{21}$ The results presented in this section draw on work by Jorge Chan-Lau in Chapter 2 of the April 2009 GFSR.

${ }^{22}$ Although recent events and the relatively low liquidity of Japan's CDS markets make the results more uncertain, it is important to keep in mind that the analysis was based on long time-series data covering the period before the severe financial dislocations induced by the Lehman collapse (July 1, 2003 to September 12, 2008).
} 
Figure II.1. Japan: A Diagrammatic Depiction of Co-Risk Feedbacks between U.S., European, and Japanese Banks

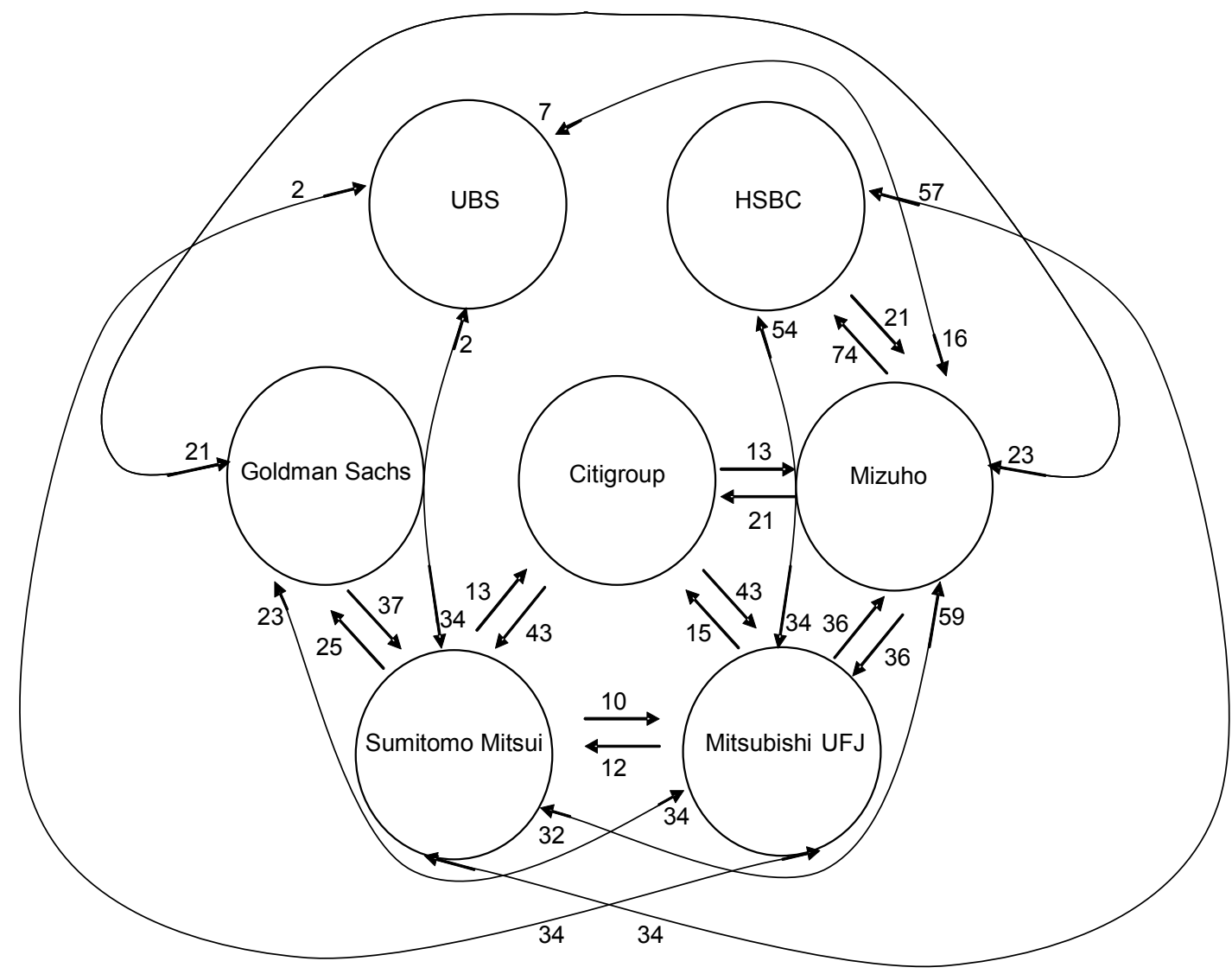

Sources: Bloomberg, L.P.; Primark Datastream; and IMF staff estimates.

Note: This diagram presents the conditional Co-Risk estimates between pairs of selected financial institutions.

\section{Conditional Co-Risk estimates suggest that the largest Japanese financial} institutions are more likely to be impacted by global financial institutions than the other way around. Drawing from CDS time series data on global financial institutions, bilateral conditional Co-Risk measures are estimated to assess which institutions were perceived by the market to be more connected to each other. Figure II.1 presents a graphical representation of some of the conditional co-risk estimates. The direction of the arrows represent the percentage increase in the CDS spread that stress in a 'source' institution would have induced on another institutions' CDS spread. ${ }^{23}$ For example, as of September 2008, had Mitsubishi been under stress, it would have induced a 15 percent increase in Citigroup's CDS spread. On the other hand, had Citigroup been under stress, Mitsubishi's CDS spread would have increased by 43 percent. This pattern is broadly similar to that observed for the other two Japanese global financial institutions in our estimation. These results are consistent with those of the network analysis which suggest that spillovers arising from Japan onto major

${ }^{23}$ An institution is said to be under stress if its CDS spread is above the $95^{\text {th }}$ percentile of its distribution. 
advanced economies - including Germany, the United States and the United Kingdom-are likely to be smaller than those affecting Japan.

\section{E. Conclusion and Future Research}

18. The analysis suggests that risks from cross-border banking spillovers-both to and from Japan - are limited overall and have generally fallen over the past year.

Network analysis suggests that, among advanced economies, the Japanese banking system is one of the most resilient to spillovers. Furthermore, the Co-Risk model suggests that Japanese banks are more likely to be impacted by market perceptions of changes in other institutions' credit risk profile, than vice versa.

19. However vulnerabilities could increase, particularly as the crisis abates. Looking ahead, if risk appetite were to recover and yen carry trades resume, cross-border exposures could rise swiftly. Similarly, spillover risks could increase in the future as Japanese banks resume the process of re-establishing their international links, which had been progressing at a brisk pace in the years before the current crisis. Indeed, Japanese banks could be in a strong position to take advantage of the global recovery by investing in financial institutions and economies abroad, as suggested by the rise in their overseas lending prior to the Lehman collapse. Hence, prudent surveillance calls for continued careful assessment of potential vulnerabilities and spillover paths, including indirect effects.

\section{Looking ahead, methods such as those discussed in the chapter could be tailored} to help policymakers in Japan and other parts of the world to strengthen their multilateral surveillance efforts. The chapter makes the case for the development and the tracking of metrics to assess direct and indirect systemic linkages. It illustrates how the analysis could aid in identifying those institutions more likely to be systemic or vulnerable under alternative credit and liquidity events. The Bank of Japan conducts comprehensive and rigorous stress tests of the banking sector on a regular basis, and is actively considering incorporating analysis of potentially systemic linkages. ${ }^{24}$ To better track the systemic implications of stress events, more detailed information will be needed by global regulators, including off-balance sheet information and data on non-bank financial institution exposures. In addition, enhanced monitoring of systemic linkages in a globalized world is likely to require information-sharing agreements between countries on cross-market and cross-border linkages.

\footnotetext{
${ }^{24}$ The results of these tests are featured biannually in the BoJ's Financial System Report, and focus on: credit risk, for which the bank relies on a credit migration model using the internal data-sets of obligor-rating transition matrices of Japanese banks; market risk for which the BoJ simulates both expected valuation changes and the unexpected losses associated with equity holdings conditioned on the stressed macro-scenarios; and interest rate risk, for which the BoJ estimates the impact of yield curve shifts and twists on banks' portfolios including bond, loan and deposit portfolios.
} 


\section{References}

Boss, Michael, Helmut Elsinger, Martin Summer and Stefan Thurner, 2005, "Network Topology of the Interbank Market," Quantitative Finance Volume 4, pp. 677-684 (Austria: Department of Finance-Complex Systems Research Group).

Brunnermeier, Markus, Andrew Crockett, Charles Goodhart, Avinash D. Persaud and Hyun Shin 2009. The Fundamental Principles of Financial Regulation. Geneva Reports on the World Economy 11. International Center for Monetary and Banking Studies.

Chan-Lau,Jorge, Espinosa-Vega, Marco, Giesecke, Kay and Solé Juan, 2009a, “Assessing Cross-Border Financial Linkages: A Network Analysis,” IMF working paper, forthcoming.

Chan-Lau,Jorge, Espinosa-Vega, Marco, Giesecke, Kay and Solé Juan, 2009b, “Co-Risk Measures to Assess Financial Systemic Linkages," IMF working paper, forthcoming.

Elsinger, Helmut, Alfred Lehar, and Martin Summer, 2006, "Risk Assessment for Banking Systems," Management Science, Vol. 52, No. 9, pp. 1301-14.

Furfine, Craig H., 2003, “Interbank Exposures: Quantifying the Risk of Contagion,” Journal of Money, Credit and Banking, Vol. 35, No. 1.

International Monetary Fund, 2009, Global Financial Stability Report, Chapter 2, April (Washington).

Márquez-Diez-Canedo, Javier and Serafín Martínez-Jaramillo, 2007, "Systemic Risk: Stress Testing the Banking System," The International Conference on Computing in Economics and Finance.

Memmel, Christoph and Ingrid Stein, 2008, "Contagion in the German Interbank Market," (Frankfurt: Deutsche Bundesbank).

Müller, Jeanette, 2006, "Interbank Credit Lines as a Channel of Contagion” Journal of Financial Services Research 29:1 37-60, 2006 (Swiss National Bank).

Upper, Christian, 2007, "Using Counterfactual Simulations to Assess the Danger of Contagion in Interbank Markets," BIS Working Paper No. 234, (Basel: Bank for International Settlements).

Upper, Christian and Andreas Worms, 2004, "Estimating Bilateral Exposures in the German Interbank Market: Is There a Danger of Contagion?)," European Economic Review 48 (2004), pp. 827-849.

Wells, Simon, 2002, "U.K. Interbank Exposures: Systemic Risk Implications," Financial Stability Review, (London: Bank of England). 


\section{Current Challenges Facing SMEs In JAPAN ${ }^{1}$}

\section{A. Introduction and Background}

\section{The global recession has had a much greater impact on Japan's manufacturing} sector than on services. In the six-month period ending in March, sales in manufacturing fell by 24 percent $(y / y)$, and operating profits by nearly 125 percent $(y / y)$ - nearly two times and four times greater than the respective declines in services. Within manufacturing, the shock affected automakers mostly, followed by semiconductors and electronics.

\section{Manufacturing small and} medium-size enterprises (SMEs) ${ }^{2}$ in particular were hit hard as the shock

\begin{tabular}{|lrrrrrrr}
\hline \multicolumn{7}{c}{$\begin{array}{c}\text { MOF Corporate Survey } \\
\text { (Oct-Mar yoy change) }\end{array}$} \\
\hline & & & & \multicolumn{3}{c}{ of which } \\
\cline { 5 - 8 } Item & Total & Non-man. & Manuf. & Auto & Elec. & Prec. \\
\hline Sales & -16.0 & -12.3 & -23.8 & -41.3 & -26.2 & -28.2 \\
Operating profits & -69.2 & -28.6 & -123.8 & -210.7 & -178.5 & -107.2 \\
Current profits & -66.5 & -28.1 & -114.9 & -161.4 & -135.5 & -104.9 \\
\hline
\end{tabular}
rippled down the entire supply chain. Large manufacturers responded quickly by slashing production and cutting costs, including from their SME suppliers. Shrinking cashflows and tighter financial conditions have put a strain on SMEs, forcing many to consolidate or exit. In some cases, large corporations have helped by lengthening the terms of receivables with key supplier, or by providing shortterm financing, while the government has stepped in with exceptional financial

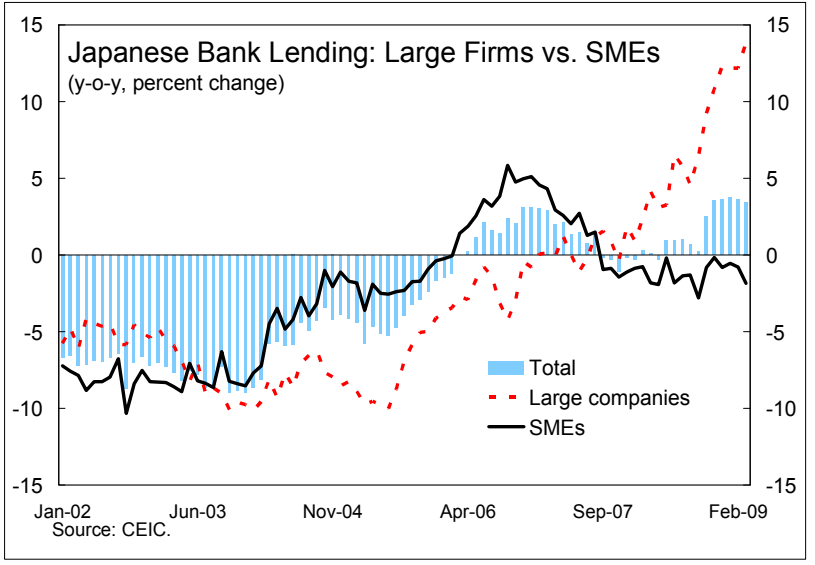
support. ${ }^{3}$ Despite these efforts, bank credit to SMEs continues to decline, while bankruptcies concentrated in manufacturing remain on the rise.

\section{Against this background, this chapter examines the financial position of the} corporate sector prior to the crisis. The analysis uses the MoF corporate survey to assess the vulnerabilities of the sector to the financial shock. The chapter also discusses how corporate restructuring can be advanced to facilitate the adjustment process, particularly among smaller firms which were in a much weaker position compared to larger firms prior to the crisis.

\footnotetext{
${ }^{1}$ Prepared by Chad Steinberg and Sumiko Ogawa.

${ }^{2}$ SMEs in manufacturing are defined as enterprises with less than $¥ 300$ million in capital or fewer than 300 workers. The criteria are lower for SMEs in wholesale, services, and retail.

${ }^{3}$ See Appendix 1 of the staff report for a summary of recent financial and corporate sector support measures.
} 


\section{B. Financial Position of the Corporate Sector}

4. The corporate sector overall has made significant progress in deleveraging. The debt-to-equity ratio has been on a trend decline since the 1970s, with the pace of deleveraging accelerating in recent years. The large drop in the debt-to-equity ratio in the non-manufacturing sector between 1997 and 2008 mainly reflects a clean-up of the real estate sector (from over 2,000 in 2000 to under 200 in 2008). Over the same period, the debt-to-equity ratio for manufacturing has almost halved. Since 1999, the nominal stock of corporate debt has fallen

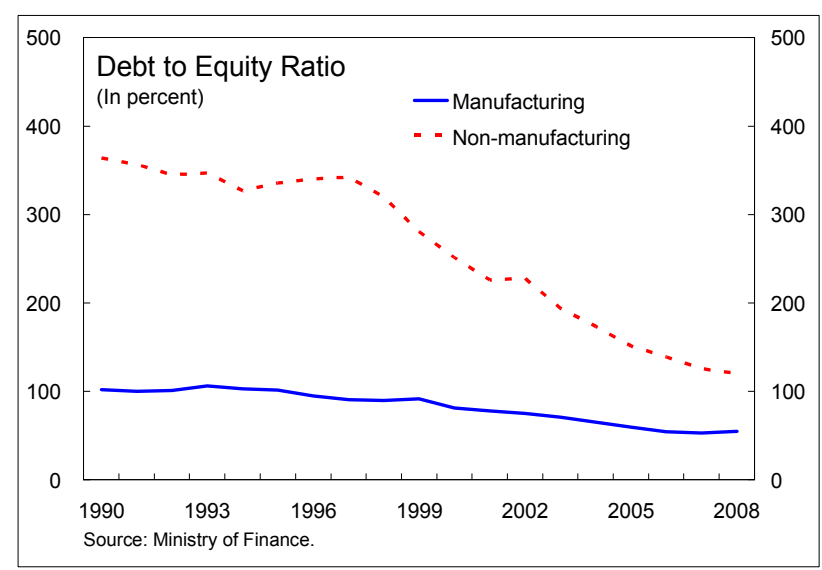
nearly 20 percent.

\section{Prior to the crisis, the corporate sector also appeared reasonably liquid, led by} improvements in non-manufacturing. The quick ratio for non-manufacturing firms rose from around 83 in 2003 to 100 in $2008 .{ }^{4}$ For manufacturing firms, the picture is more mixed, as a decline in liquidity for large firms offset improvements by SMEs. The difference could be attributed to financing conditions, as SMEs raised precautionary savings in response to tighter credit conditions, while larger firms may have drawn down their cash reserves with improved access to capital markets.
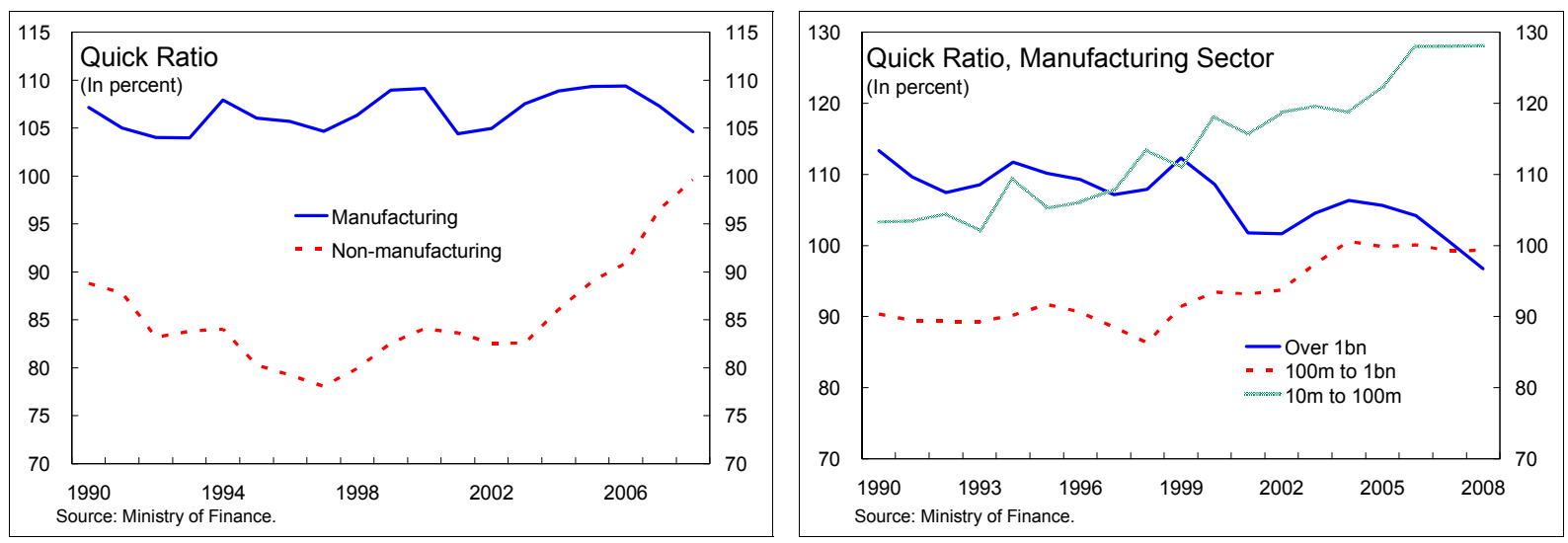

\section{Profit margins in the manufacturing sector recovered somewhat as excess}

capacity declined. Up to 2008 , the improvement in manufacturing profitability, measured by return on assets, was greater than for non-manufacturing, rising from around 3 percent in the

\footnotetext{
${ }^{4}$ Quick ratios measure the ability of a company to use its near cash or quick assets to immediately extinguish or retire its current liabilities; a quick ratio above 100 percent is a good benchmark.
} 
mid-1990s to just over 5 percent prior to the current crisis. Separating the calculation of ROA into two components reveals that the improvement reflects both an improvement in asset turnover (operating revenue / total assets) — a measure of asset utilization — and profit margins (net income / operating revenue). Capacity utilization was over 100 percent just prior to start of the current downturn.
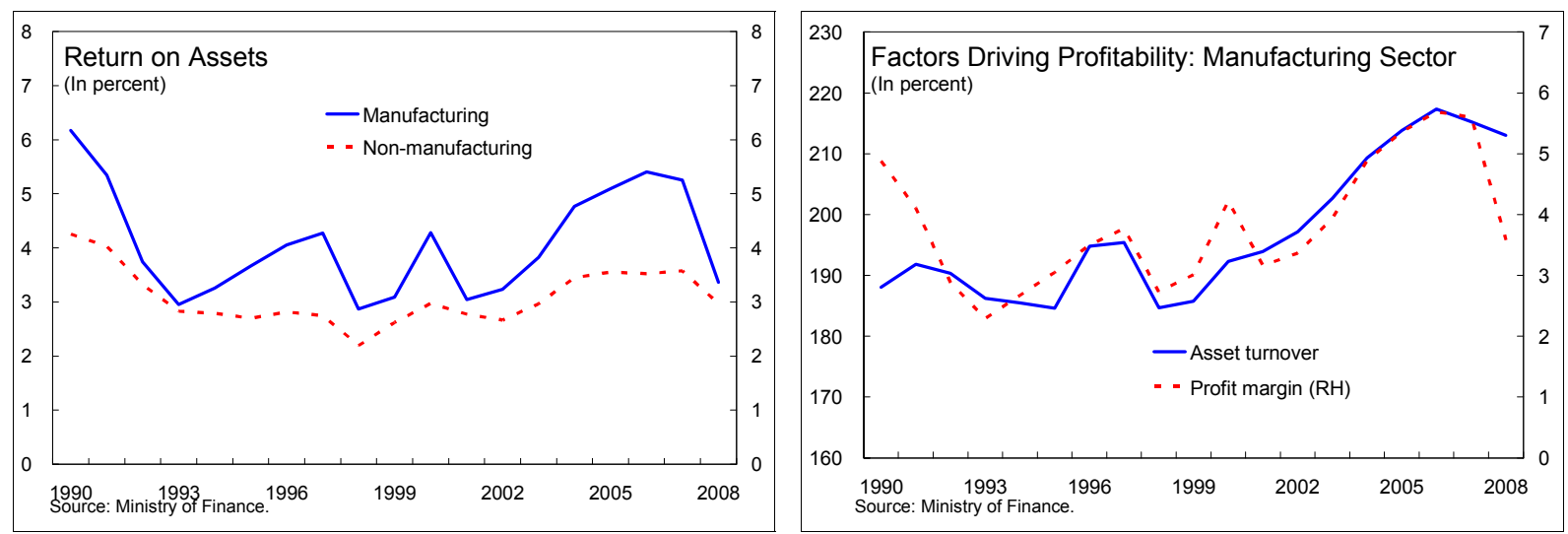

7. Improving profitability and lower borrowing rates have strengthened the capacity of the corporate sector to remain current on its debt obligations. Interest coverage ratios (ICR = operating profits divided by interest expense) have risen steadily, from 1.5 in the mid-1990s to 6.7 in 2007 . The rise is even more dramatic for the manufacturing sector, which reached 13 in 2006. This reflected both improved cash flow and the sharp fall in average borrowing rates, which have declined to just under 2 percent along with the concurrent decline in government yields since 1991.
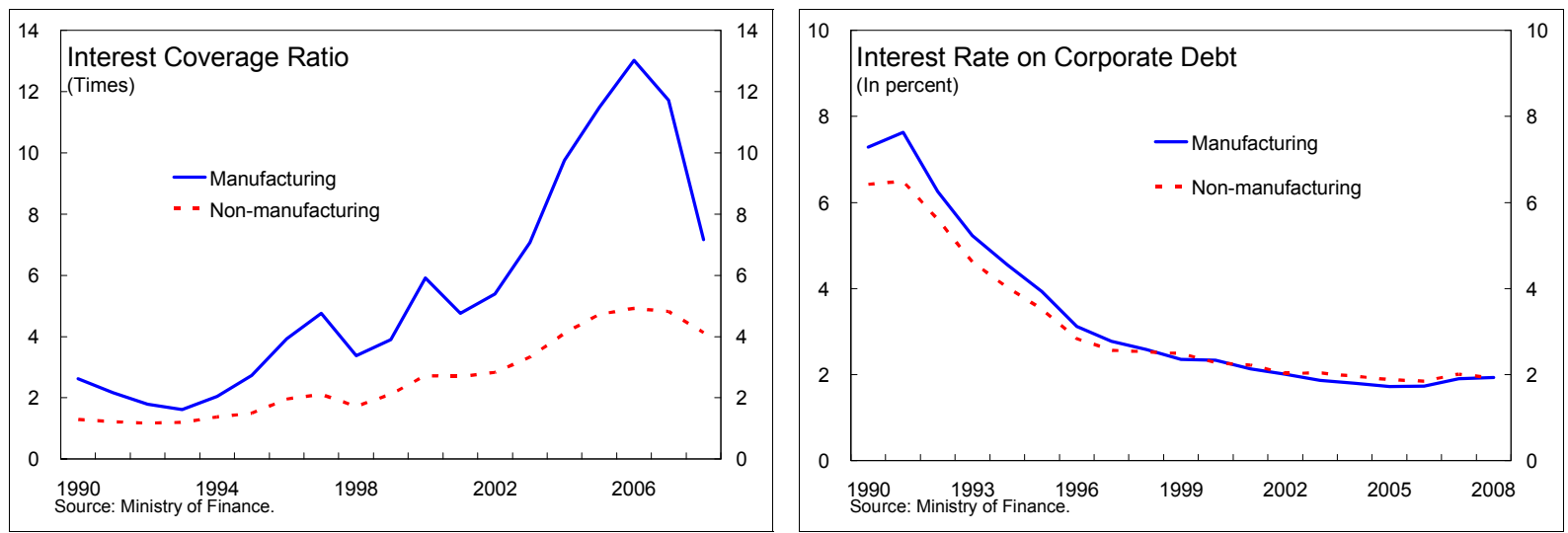

\section{The improvements in the aggregate figures, however, mask structural}

weaknesses among SMEs. A breakdown by firm size shows that in 2008, SMEs suffered from significantly higher leverage and lower profitability than larger firms. Compared to large firms, debt-equity ratios for SMEs were nearly three times as high and profitability, as measured by ICR, four times lower. The difference in part reflects the more aggressive deleveraging by larger corporations after the late 1990 banking crisis. By sector, profitability in the electronics sector has lagged behind improvements in other export-industries. 

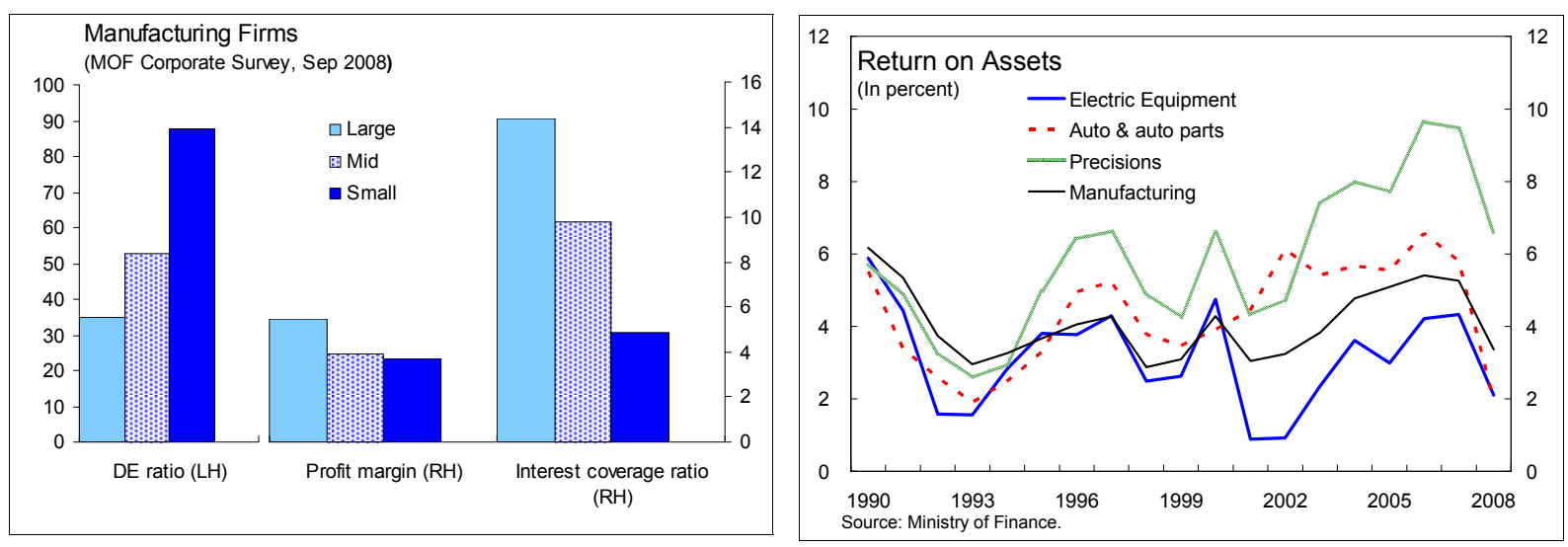

9. To summarize, smaller firms entered the crisis with much weaker balance sheets and lower profitability than larger firms. Although overall debt levels in 2008 were lower, profits margins greater, and liquidity ratios higher relative to the 1990s banking crisis, this improvement was concentrated mainly among larger firms. Smaller firms with higher leverage ratios and lower profitability were left more vulnerable to the slowdown, highlighting the greater need for restructuring for this sector.

\section{Promoting Restructuring of the Corporate Sector}

10. Spurred by the previous banking crisis, Japan has made considerable progress in improving its framework for bankruptcy (Box III.1). Important advances include:

- Simplification of bankruptcy court procedures, a reduction in administrative costs, and the revision of the Bankruptcy Law in 2004. Consequently, the percent of court-administered bankruptcies in the total number of bankruptcies rose from under 10 percent in 1994 to close to 67 percent in 2008 .

- Passage of the Civil Rehabilitation Law (CRL) in 1999. The CRL simplified the court-led restructuring processes-similar to the U.S.'s chapter 11. The law was originally aimed at medium-sized firms and SMEs but gained popularity amongst larger firms as well because it allowed management to remain in place. Since its passage, over 6,000 firms have been successfully restructured.

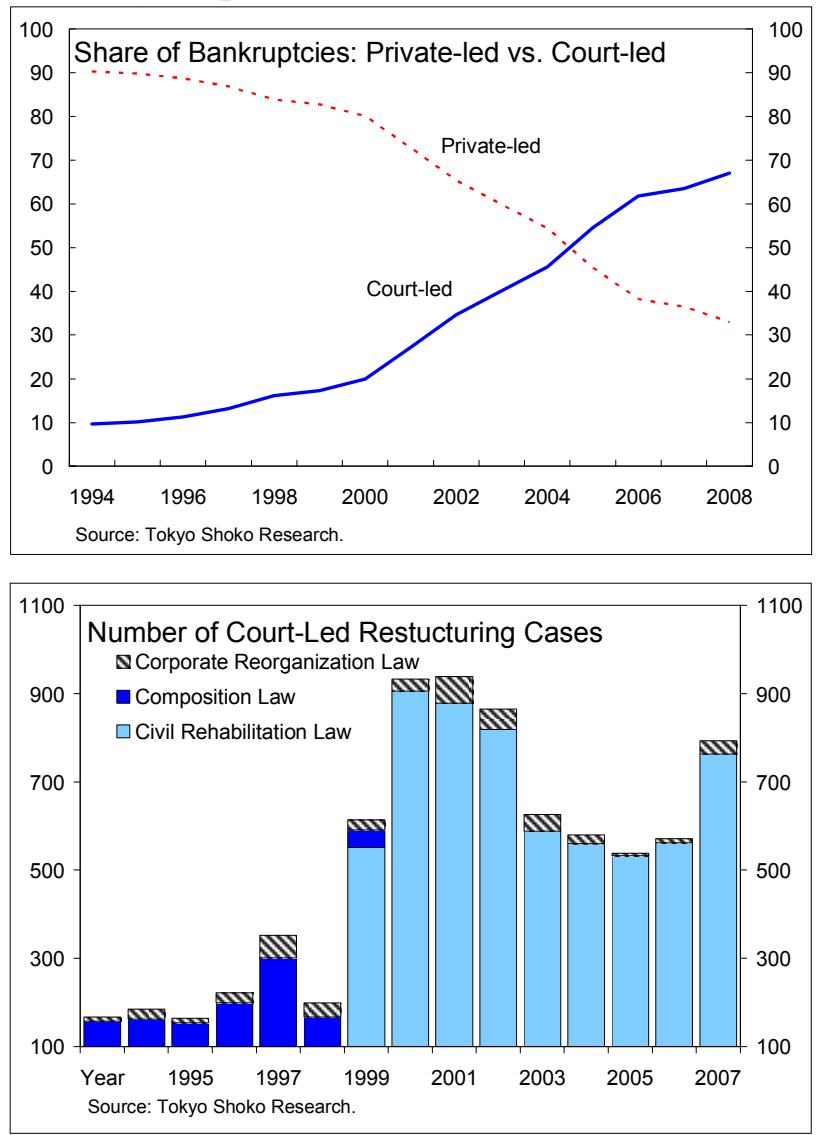




\section{At the same time, efforts have been made to increase out-of-court workouts.}

In 2001, guidelines were introduced for large corporations, which helped improve the transparency of the process. Through 2005, at least 30-40 firms had successfully used the process. For SMEs, METI has introduced SME support centers in each regional government (47 total). Since their inception, the centers have held discussions with over 17,000 SMEs, of which it has helped formulate 2,100 restructuring plans. The restructuring plans have mainly resulted in debt rescheduling (63 percent) or debt forgiveness ( 23 percent), with the number of firms receiving debt-for-equity or debt-for-debt swaps relatively low at around 10 percent. To provide needed financing, METI has also encouraged the establishment of 17 SME restructuring funds, but these funds have been underutilized. Of the $¥ 51.5$ billion raised, only $¥ 25.7$ billion has been disbursed to 131 companies.

\section{Promoting the restructuring of SMEs could provide significant benefits to the} economy. SMEs are an important part of the Japanese economy. They account for over 50 percent of manufacturing shipments and 25 percent of exports and investment. They span many industries and historically have served as key suppliers to large manufacturing firms. SMEs account for 70 percent of employment and in recent years have been a major source of jobs for the economy. The SME sector can play a vital role in fostering new employment opportunities and raising overall productivity, but have been held back by long-standing structural weaknesses.

\section{Both price incentives and institutional settings help explain the lack of progress within the SME sector, with some of the major barriers including:}

- SMEs have been cushioned by easy financing. Since the early 2000s, a weak yen, low interest rates, and a government guarantee on financing have shielded SMEs from making difficult tradeoffs. Of the total loans outstanding to SMEs, roughly $10-15$ percent are covered by a government guarantee.

- Creditors have few incentives to restructure. From the creditors standpoint, SMEsrelative to larger corporations - have increasingly sourced loans from multiple banks making it more difficult for a main bank to induce reform. Furthermore, the size of the loans are usually not large enough for a bank to invest the time needed to restructure smaller firms or help them merge with other firms in the region.

- Debtors are unable to make a new start. For debtors, the stigma associated with a bankruptcy and the inability of management to make a fresh start following procedures has strongly discouraged firms from asking for assistance early on in the process. Some deterrents for bankruptcy filing include a historically low home exemption (which was recently raised from around $\$ 3,000$ to $\$ 9,000$ ) in personal bankruptcies and the widespread use of guarantees, thus making default an unattractive option. 
14. How then can restructuring be facilitated? Some ideas include:

- Improving consultative services. The SME support centers are a step in the right direction, but the number of qualified personnel is still insufficient.

- Making the out-of-court process more transparent and less costly. Introducing guidelines for out-of-court workouts for SMEs - as was done for large corporations in 2001—could help improve transparency. At the same time, introduction of more out-of-court alternatives could help lower the costs to restructuring. One alternative that has been tried recently is the adoption of Alternative Dispute Resolution (ADRs) courts. In addition, under the revision of the Industrial Revitalization Law, tax breaks and subsidized financing will be offered to SMEs that successfully spin-off the viable components of their business as a new company.

- Providing new financing for restructuring. A public asset company similar to the ICRJ, could be restarted to assist banks in working out viable but distressed firms by providing new financing and helping resolve creditor disputes. A bill, Kigyo Saisei Shien Kiko Ho, providing such a framework for medium-sized firms is currently being discussed in the Diet. Expanding the availability of other financing, such as DIP financing, or making better use of existing SME funds could also provide the needed incentives.

- Facilitating start-ups. Recent efforts by the government to establish a public-private partnership, Sangyo Kakushin Kiko, targeted at funding advanced and innovativetechnology industries could provide some needed incentives. (The government plans to provide $¥ 82$ billion in initial funding.)

\section{Conclusions}

\section{An analysis of the corporate sector highlights that SMEs with their weaker} balance sheets and lower profitability were more vulnerable to the global slowdown than larger firms. Restructuring through either out-of-court workouts or the bankruptcy system could help Japanese SMEs to strengthen their balance sheets, improve core profitability, and reorient themselves to the new global environment, much in the way that the large corporates sector did after the 1990s banking crisis. A vibrant SME sector could assist in the adjustment process by absorbing labor and capital from manufacturing. 


\section{Box III.1. Court-Led Options for Financially Distressed Firms}

Japan has made considerable progress in improving its framework for restructuring. An overhaul of the system began in 1996, with successive reforms starting in 1999.

- 1999: Enacted the Civil Rehabilitation Law introducing a new chapter 11-style procedure for smaller firms.

- 2002: Revised Corporate Reorganization Law streamlining processes and easing criteria for application. Allowed Tokyo and Osaka courts to administer cases throughout Japan.

- 2004: Revised the Bankruptcy Law helping streamline processes.

- 2005: Enacted a new Corporate Law, which helped clarify procedures for liquidation.

Within the court system, firms have broadly three choices.

Civil Rehabilitation Law (Chapter 11 for medium and small size firms). The law facilitates restructuring under bankruptcy procedures. (It replaces an older Composition Law.) In 2008, more than 763 firms filed for CRL protection, relative to only 300 hundred firms at the peak of the old Composition Law in 1998. While it is intended for small to medium size firms, large firms have been known to use its procedures. The application and approval process is relatively quick, usually taking 5 months, with the full process expected to be completed within 10 years. A key differentiating factor is that management is usually allowed to stay in place, often referred to as Debtor-In-Possession (DIP). Secured creditors usually fall outside of its jurisdiction, unless there are extenuating circumstances. Unsecured creditors approve the rehabilitation plan.

Corporate Reorganization Law (Chapter 11 for large firms). The procedures are more comprehensive and are geared toward large corporate bankruptcies. Only 30 firms filed under this procedure in 2008. Management is usually replaced by a court-appointed receiver, but this is not required. DIP procedures were codified in the 2002 revisions, resulting in a few DIP cases recently in Tokyo courts. The process is somewhat longer than CRL, with the application and approval process taking up to one-year, and with the full process expected to be completed within 15 years. The court may order a stay if necessary to protect the firm from creditor harassment. Secured creditors, unsecured creditors, and shareholders approve the reorganization plan.

Bankruptcy Law (Chapter 7). Established for insolvent firms to ensure an orderly exit. This is the most common form of bankruptcy, with 9,351 cases in 2008. A court-appointed receiver administers the process. Secured creditors can access their rights under the procedures. 